
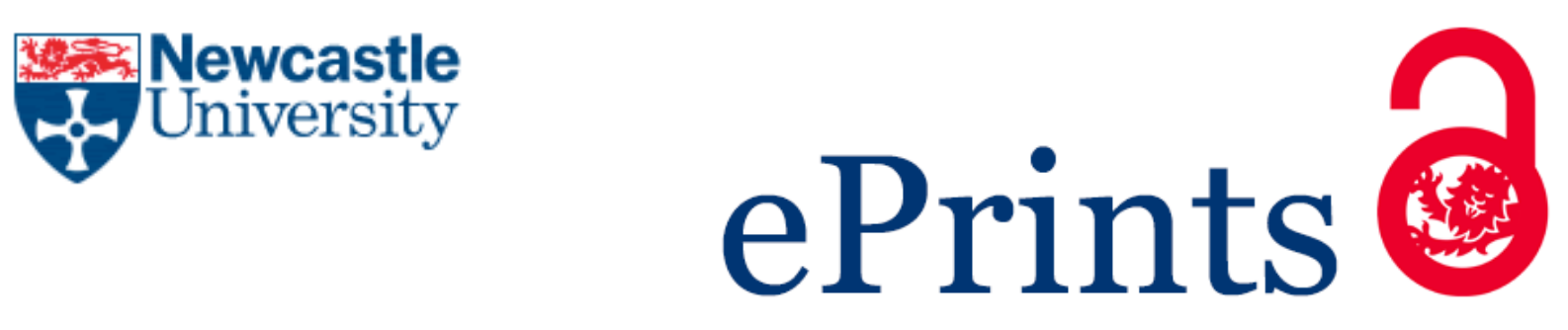

Lu YJ, Roskilly AP, Yu XL, Tang K, Jiang L, Smallbone A, Chen LF, Wang YD.

Parametric study for small scale engine coolant and exhaust heat recovery

system using different Organic Rankine cycle layouts.

Applied Thermal Engineering 2017, 127, 1252-1266.

\title{
Copyright:
}

(C) 2017. This manuscript version is made available under the CC-BY-NC-ND 4.0 license

DOI link to article:

https://doi.org/10.1016/j.applthermaleng.2017.08.128

Date deposited:

$04 / 09 / 2017$

Embargo release date:

30 August 2018

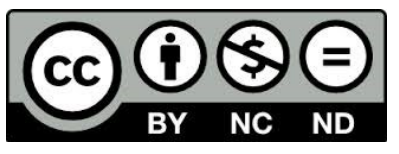

This work is licensed under a

Creative Commons Attribution-NonCommercial-NoDerivatives 4.0 International licence 


\section{Parametric study for small scale engine coolant and exhaust heat 2 recovery system using different Organic Rankine cycle layouts}

3 Yiji Lu ${ }^{\mathrm{a}, *}$, Anthony Paul Roskilly ${ }^{\mathrm{a}}$, Xiaoli Yu ${ }^{\mathrm{b}}$, Ke Tang ${ }^{\mathrm{a}}$, Long Jiang ${ }^{\mathrm{a}}$, Andrew Smallbone ${ }^{\mathrm{a}}$,

4 Longfei Chen ${ }^{\mathrm{c}, *}$, Yaodong Wang ${ }^{\mathrm{a}}$

5 a Sir Joseph Swan Centre for Energy Research, Newcastle University, Newcastle, NE1 7RU, UK

$6 \quad{ }^{b}$ Department of Energy Engineering, Zhejiang University, Hangzhou, 310027, China

7 ' School of Energy and Power Engineering, Energy and Environment International Center, Beihang University, Beijing, 100191, China

\section{$8 \quad$ H I G H L I G H T S}

9 - Four engine coolant and exhaust heat recovery ORC systems are studied

- Using scroll expander for small scale engine waste heat recovery are investigated

- Effects of using the proposed ORC systems on overall ICE performance are studied

- Solutions for fully recovering coolant energy from ICE for engine WHR are proposed

Abstract

This paper presents the study of four different engine coolant and exhaust heat recovery Organic Rankine Cycle systems using R245fa as working fluid and scroll expander as expansion machine. The parametric investigation suggested the fluid superheating temperature has limited influence on the simple structured ORC system (ORC_sim) with overall efficiency about $6.2 \%$ and average produced power around $0.59 \mathrm{~kW}$ under engine rated condition. The maximum rotational speed of the scroll expander is around $4000 \mathrm{rpm}$ under different ratio of coolant and exhaust ratio of the Yanmar engine $(6.8 \mathrm{~kW})$, which means the designed ORC system can be easily used for electricity generation by directly connecting expander shaft to a conventional electrical generator. The BSFC reduction ratios of ICE+ORC_sim, ICE+ORCR_1 and ICE+ORC_pre under engine rated power are respectively $6.1 \%$, $7.4 \%$ and $5.2 \%$. And the overall effective energy efficiency by integrating ORC_sim, ORCR_1 and ORC_pre to the ICE can be improved by $6.5 \%, 8.0 \%$ and $5.4 \%$ under engine rated power condition.

\footnotetext{
* Corresponding author. Tel.: +44 (0) 1912084827

E-mail address: yiji.lu@ncl.ac.uk; luyiji0620@gmail.com (Y.Lu); chenlongfei@buaa.edu.cn (L. Chen)
} 


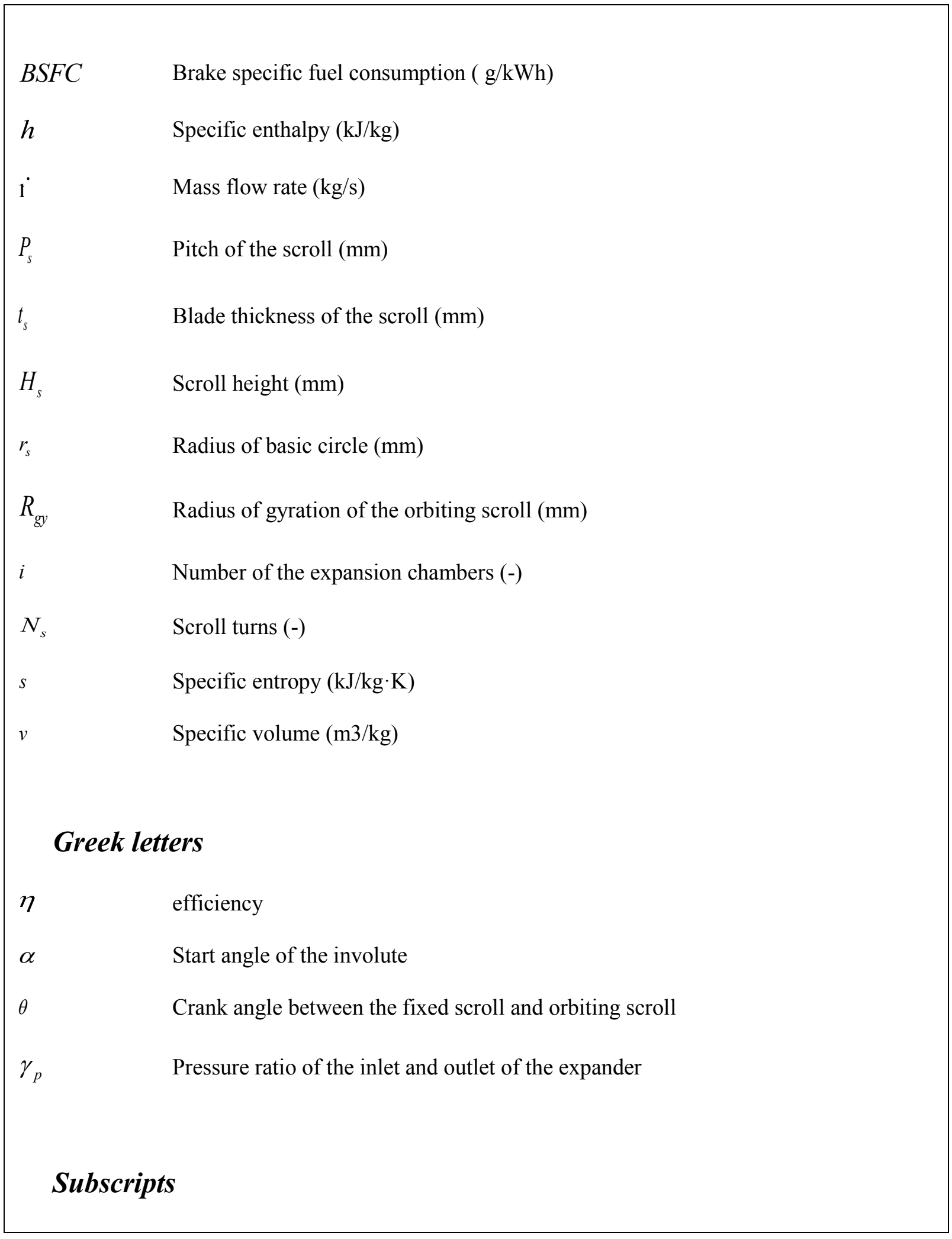




\begin{tabular}{|c|c|}
\hline$b$ & brake \\
\hline$p$ & pump \\
\hline pre & using coolant as preheater in ORC \\
\hline$r$ & recuperator \\
\hline$e x$ & exhaust \\
\hline$e x_{-} s$ & Working condition at the expander exhaust after isentropic expansion process \\
\hline int & Internal working condition of the fluid during expansion process \\
\hline isen & isentropic \\
\hline su & supply \\
\hline pre & ORC system using coolant energy as preheater \\
\hline \multicolumn{2}{|c|}{ Acronyms } \\
\hline$C N G$ & Compressed Natural Gas \\
\hline$I C E$ & Internal Combustion Engine \\
\hline$O R C$ & Organic Rankine Cycle \\
\hline ORCR & Organic Rankine Cycle with Recuperator \\
\hline WHR & Waste Heat Recovery \\
\hline
\end{tabular}




\section{Introduction}

Heat driven energy systems attract ever increasing attentions due to the oncoming energy crisis and environment problems caused by burning conventional energy resources such as oil, natural gas and coal. The Organic Rankine Cycle (ORC) has been widely recognised as one of the most promising technologies to convert heat into mechanical power or electricity $[1,2]$. Various heat sources can be used to drive ORC system including biomass combustion, solar energy, geothermal heat, industry wasted heat and heat from Internal Combustion Engine (ICE) [1]. A typical ICE converts about $30 \%$ of the fuel energy into effective mechanical power and around $60-70 \%$ energy is wasted from the exhaust system and cooling system of ICE [3, 4]. A well designed ORC system can effectively improve the overall energy efficiency and reduce $\mathrm{CO}_{2}$ emissions of the Internal Combustion Engine (ICE) with around 2 to 5 years payback period through fuel saving [2-4].

The overall efficiency of a typical ORC is determined by the designed evaporation and condensation temperature. When the condensation temperature is fixed, the higher of the evaporation temperature, the higher overall ORC efficiency can be achieved. For the on road vehicle application, the condensation temperature is controlled by the radiator and the lowest condensation temperature is normally about $40{ }^{\circ} \mathrm{C}$. The majority studies of Waste Heat Recovery (WHR) from ICE focus on the engine exhaust energy [5], because the exhaust temperature of ICE is various from $200-700{ }^{\circ} \mathrm{C}$, which is much higher than the coolant temperature $[3,4]$. Song et al. [6] reported a performance analysis to recovery exhaust energy from a stationary Compressed Natural Gas (CNG) engine. The analysis results pointed out the ORC system can potentially improve the electric efficiency of the CNG engine by a maximum $6.0 \%$ and the overall engine Brake Specific Fuel Consumption (BSFC) can be reduced by a maximum $5.0 \%$ [6]. The effects of fluids and parameters of the ORC system for engine exhaust heat recovery have been deeply studied and reported by Tian et al. [7], who considered 20 fluids (boiling point range from -51.6 to $32.05{ }^{\circ} \mathrm{C}$ ) to evaluate the cycle parameters such as the overall thermal efficiency, expansion ratio, effective power output and electricity production cost. Results 
suggested R141b, R123 and R245fa can achieve the highest thermal efficiency ranging from $16.6 \%$ to $13.3 \%$ with the lowest electricity production cost from 0.30 to $0.35 € / \mathrm{kWh}$ [7]. Zhao et al. [8] reported the performance evaluation of a diesel engine integrated with ORC system. Results pointed out the Brake Specific Fuel Consumption (BSFC) reduction and the overall thermal efficiency of the engine integrated with ORC unit is $3.61 \mathrm{~g} /(\mathrm{kWh})$ and $0.66 \%$. The alkane-based working fluids have been recommended to be used for diesel engine exhaust heat recovery considering the technical and economic point of view [9]

Engine coolant energy is normally recognised as a heat source that is not worth to recover because the coolant temperature is about $80-100{ }^{\circ} \mathrm{C}$, which can only provide $40-60{ }^{\circ} \mathrm{C}$ temperature difference to drive the ORC of vehicle. Several researchers pointed out the coolant energy contains about $30 \%$ of the fuel energy, which could be potentially utilised in the ORC waste heat recovery system of the ICE to improve the ORC system efficiency and reduce the payback period of the overall cost with a proper designed system $[1,2]$. Yu et. al [10] adopted the coolant energy to preheat the ORC fluid for the recovery of both coolant and exhaust heat from a diesel engine. The simulation results suggested about $75 \%$ of exhaust heat and $9.5 \%$ coolant energy can be recovered under engine conditions from high to low load [10], which means a lot of coolant energy has been wasted by using the designed ORC system. Lu et al. [11] reported the designed and assessment of an ICE waste heat recovery cogeneration using ORC as the power generation system to recover both coolant and exhaust energy from a 4 cylinders diesel engine. The steady study pointed out the ICE integrated ORC can potentially improve the overall efficiency of the ICE by $3 \%$ and reduce the BSFC from $210 \mathrm{~g} / \mathrm{kWh}$ to $190 \mathrm{~g} / \mathrm{kWh}$ under the engine full load conditions [11]. The other potential approach for engine coolant and exhaust recovery is using dual-loop ORC, which adopts two separately ORC systems to regenerate multi heat sources from ICE [12-14]. Wang et al. $[12,13]$ conducted the study on a dual loop ORC to evaluate the performance on a gasoline engine and a light-duty diesel engine. Detailed operational maps for the selected gasoline engine and diesel engine using the dual loop ORC have been reported. 
Results indicated the absolute effective thermal efficiency of the gasoline engine can be increased by $3-6 \%$ throughout the engine operating region [12] and the maximum thermal efficiency increase in the light diesel engine can be achieved by as high as $8 \%$ [13]. Shu et al. [14] conducted further study on the dual-loop ORC for engine coolant and exhaust recovery and pointed out the influence of using different working fluids. Six working fluids have been selected for the low temperature cycle and the high temperature loop adopted water to recovery the exhaust energy [14]. The maximum overall exergy efficiency of the dual-loop ORC system can be as high as $55.05 \%$ using R1234yf as working fluid [14]. However, the dual-loop ORC requires two set of ORC system components and advanced controlling strategies to balance the different heat sources.

On the other hand, the selection of expansion machines is critical for the ORC system performance [3, 4]. For small scale applications, scroll expanders are recognised as the optimal expansion candidate because of its high reliability, relatively high isentropic efficiency and broad availability [15]. A one dimensional scroll machine model was built to predict the working curves of the scroll machine operating as expander [16]. The ORC numerical model has been used to evaluate the performance of the micro CHP system for the heat recovery of ICE and solar energy recovery [16]. The results suggested a solar thermal collector with $20 \mathrm{~m}^{2}$ was capable to produce $1 \mathrm{~kW}$ electric power using scroll expander and $10 \mathrm{~kW}$ heat as the form of hot water [16]. Muhammad et al. [17] reported the experimental investigation of a $1 \mathrm{~kW}$ ORC system using R245fa as the working fluid to recover the heat from waste steam in the range of 1-3 bar. Results indicated the maximum electrical power output from the system was $1.016 \mathrm{~kW}$ with $5.64 \%$ system thermal efficiency and $58.3 \%$ scroll expander isentropic efficiency [17]. June et al. [18] adopted a $1 \mathrm{~kW}$ oil-free scroll expander using zeotropic mixture with $48.5 \% \mathrm{R} 245 \mathrm{fa}$ and $51.5 \% \mathrm{R} 365 \mathrm{mfc}$ in an ORC system to recover the exhaust gas from a $30 \mathrm{~kW}$ gas turbine. The experimental results pointed out the overall efficiency of the ORC system was about $3.9 \%$ [18]. The authors pointed out the efficiency of the scroll expander was only $28.4 \%$, which means the scroll device has been operated within the over-expansion region and the 
overall ORC efficiency can be much higher than 3.9\% if the scroll expander has been operated within the optimal conditions [18]. Muhammad et al. [17] reported the maximum electrical power from an oil free scroll expander was $1.016 \mathrm{~kW}$, when the system thermal efficiency was $5.64 \%$ and the isentropic efficiency of the expander was $58.3 \%$. The maximum ORC thermal efficiency has been achieved at $5.75 \%$, when the scroll expander achieved the maximum isentropic efficiency, which was as high as 77.74\% during the experiment [17]. A small scale ORC prototype has been built at the Energy Systems Laboratory of Cassino University. Under the heat source temperature about $100{ }^{\circ} \mathrm{C}$, the maximum electrical output from the mini ORC system was about $1 \mathrm{~kW}$ with $9 \%$ thermal efficiency and about $20 \mathrm{~kJ} / \mathrm{kg}$ specific work when the isentropic efficiency of the scroll expander was $84.9 \%$ [19]. However, the designed operational ORC fluid state point has been located at the two phase region [19], which will damage the scroll device for long time operation, which means a proper parametric study to avoid this issue is important and necessary. Quoilin et al [20] developed a semiempirical scroll expander model by converting the original scroll compressor model proposed by Winandy et al. [21]. The semi-empirical scroll expander model was used and adopted by Mendoza et al. [22] to compare with the experimental results of an open drive scroll expander using ammonia and air as working fluid. The semi-empirical scroll expander model has been widely used by the researchers and shown good agreement to predict the expander performance [23-25]. However, the semi-empirical scroll expander model requires eight predefined parameters, which requires a lot of experimental results to identify the parameters [26]. The latest investigation on ORC using scroll expander was reported by Yang et al. [27], who modified an originally hermetic type refrigerant scroll compressor with built in volume ratio at 3.24 operating as an expander. The maximum shaft power and thermal efficiency of the ORC system was $2.64 \mathrm{~kW}$ and $5.92 \%$, respectively [27].

Therefore, the study of different single loop ORC system for engine different heat sources recovery is important in order to promote the application of this technology. In this study, the design and investigation of single loop ORC system using a targeted scroll expander to recover both coolant 
and exhaust energy from an ICE is reported. Four different ORC system layouts are proposed and the

129 performances of these four ORC systems are compared under variable heat source ratio of coolant and

130 exhaust energy from the ICE. The study pointed out the advantages of using a simple designed ORC

131 system to fully recover both the coolant and exhaust energy from the ICE for on road vehicle

132 application, which has been hardly reported and noticed in previous studies because the coolant

133 energy from engine is commonly recognised as not worth for recovering and engine exhaust ORC

134 system can achieve high overall thermal efficiency. Moreover, the parametric study on the optimal

135 ORC systems using a targeted scroll expander have been conducted in order to evaluate the

136 performance and provide essential data for the selection of components.

\section{Description of the designed engine waste heat recovery system}

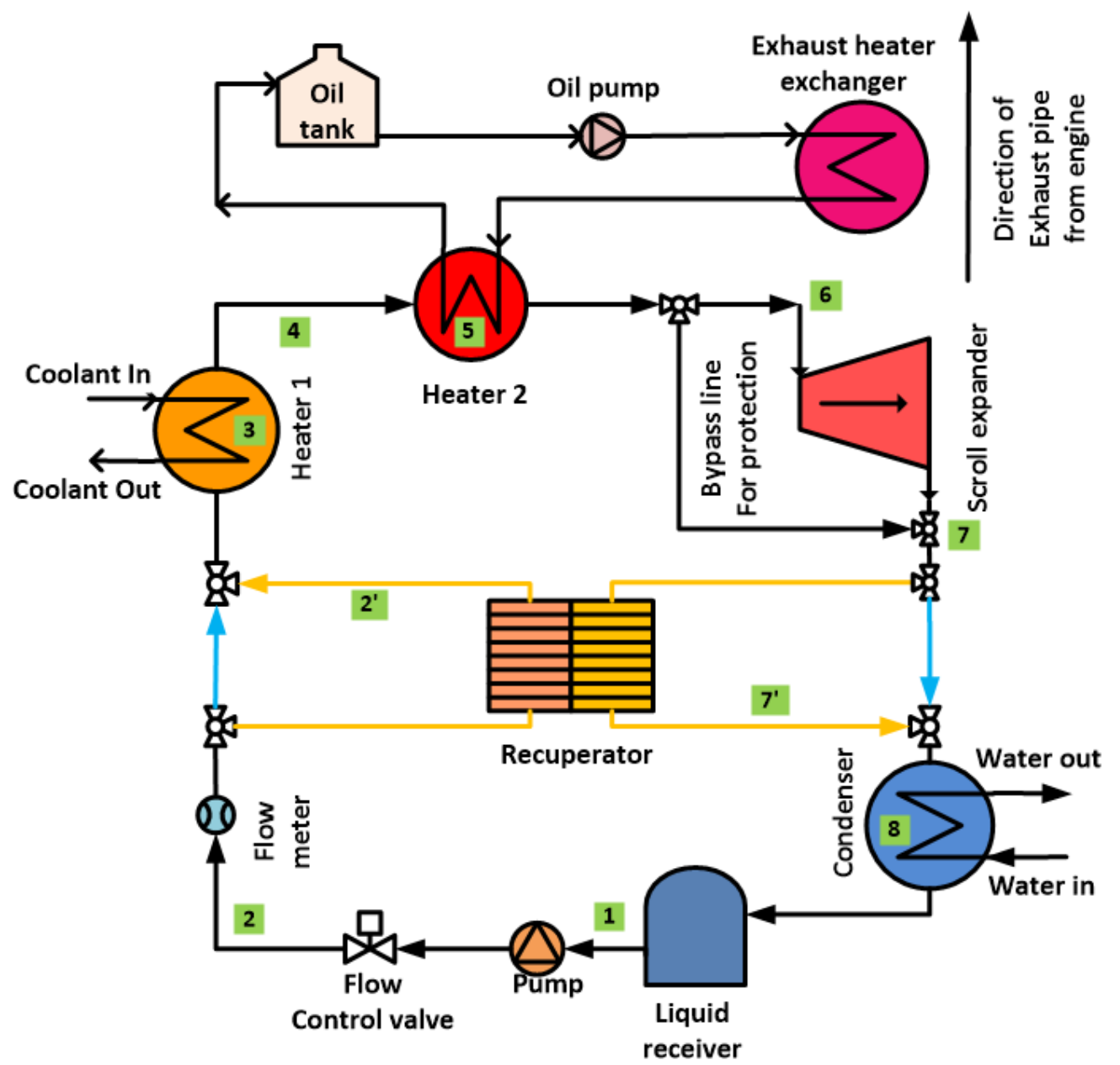

(a) 


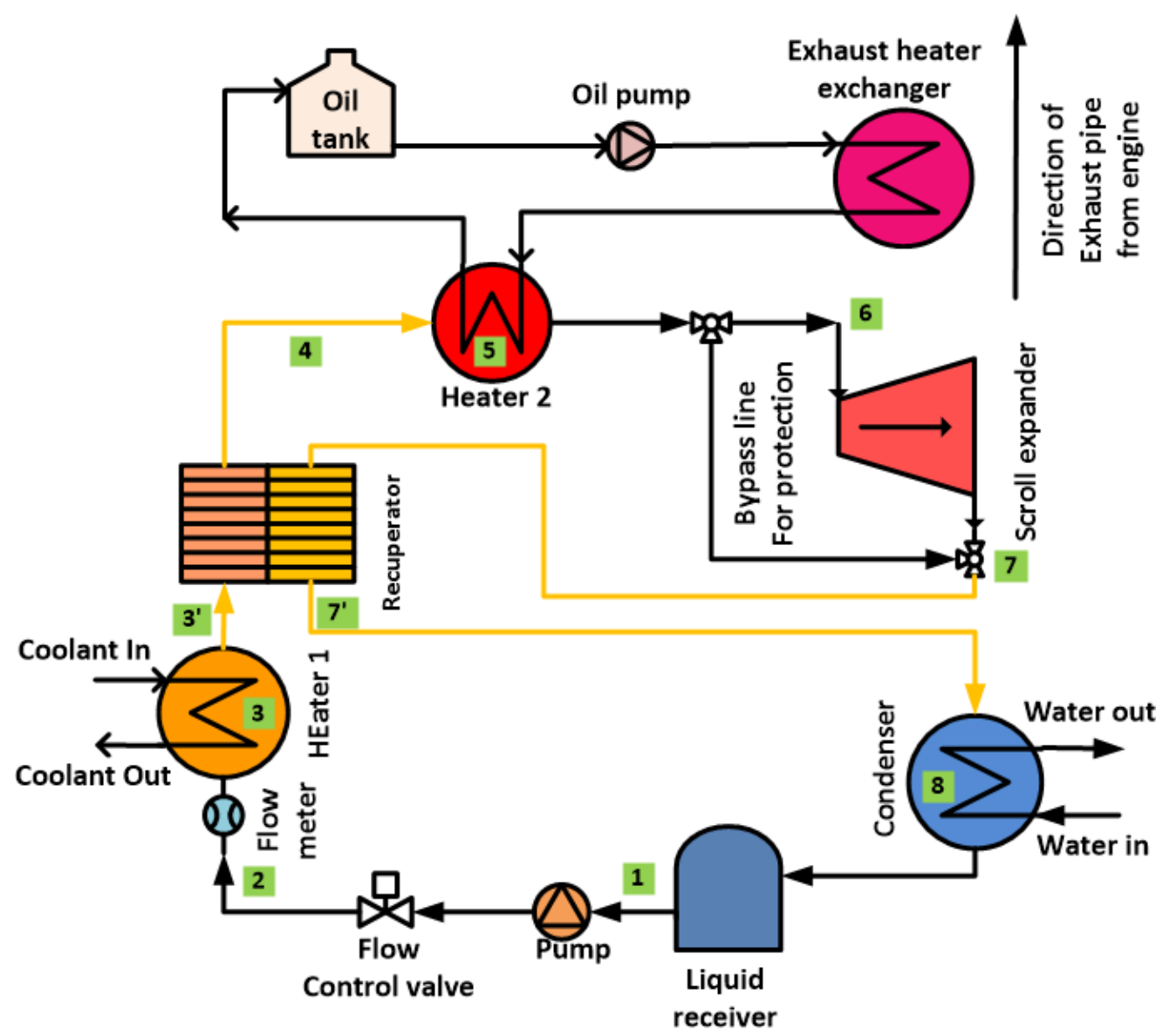

(b)

Fig. 1. Schematic diagram of the ORC for engine coolant and exhaust recovery

(a) blue line-ORC without recuperator, orange line-ORC with recuperator before coolant heat exchanger (b) ORC with recuperator between coolant and exhaust heat exchangers

The ORC system employed here includes two heaters, a recuperator, a scroll expander, condenser, liquid receiver and pump as shown in Fig 1. Two system layouts are illustracted in Fig. 1 (a), which

140 includes the conventional ORC as illustrated by blue line and the ORC with recuperator as shown in

141 yellow line. The recuperator is located after the fluid pump and before the coolant heat exchanger as a

142 preheater to reuse the exhaust energy from the scroll expander in Fig. 1 (a). The other type of engine

143 coolant and exhaust recovery ORC system with recuperator is shown in Fig. 1 (b), which applies the 144 recuperator as an addition heater during the vaporization of refrigerant when the recuperator locates between the Heater 1 and Heater 2. The coolant water from the ICE is supplied to Heater 1, which heats up the working fluid in two phase condition. The energy from the exhaust is recovered using a

147 heater exchanger located on the exhaust pipe. Thermal fluid is used to transfer the exhaust energy 
from exhaust heater exchanger to Heater 2, where the working fluid is heated up to the designed working condition to start the expansion process inside the scroll expander. Because the existing of

150 liquid fluid flows into the scroll expander will damage the expansion machine, a bypass line is

151 designed to protect the expander when the desirable working conditions have not been reached. The condenser rejects the unrecoverable heat into the environment by transferring the heat to the water cooling system. A liquid receiver is located at the inlet of the pump in order to maintain sufficient

154 liquid ORC working fluid pumped to the ORC system.

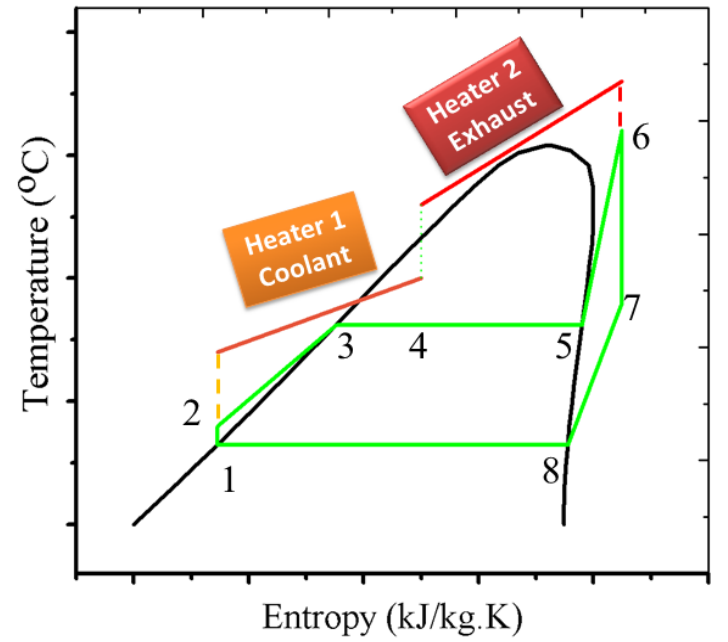

(a)

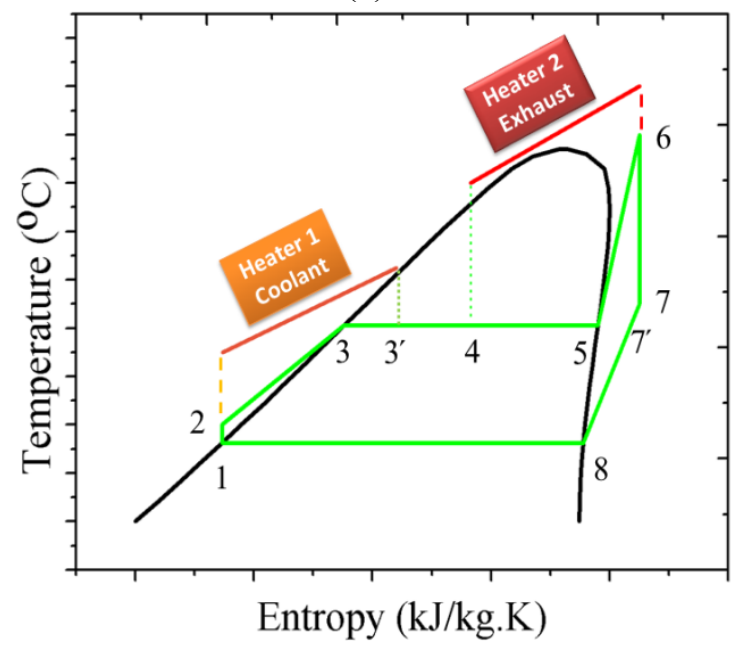

(c)

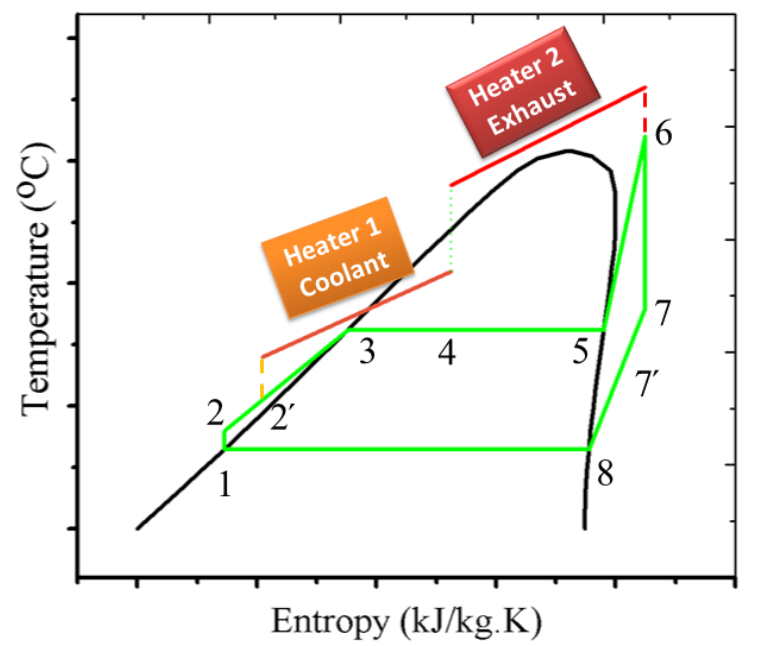

(b)

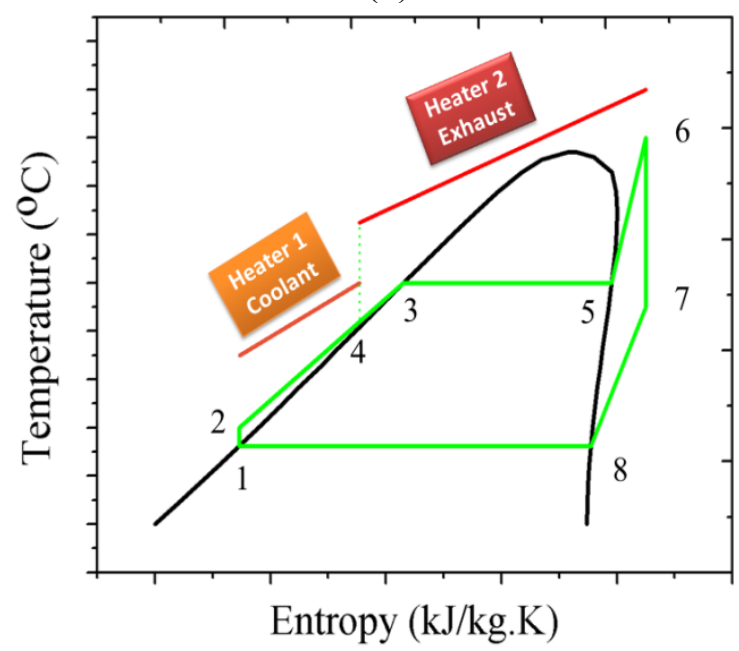

(d)

Fig. 2. T-s diagram of four different ORC system layouts

(a) Coolant and exhaust fully recovery ORC_sim system

(b) Coolant and exhaust fully recovery ORCR_1 system (recuperator between pump and Heater 1)

(c) Coolant and exhaust fully recovery ORCR_- 2 system (recuperator between Heater1 and Heater2) (d) Conventional engine coolant and exhaust recovery ORC_pre system (coolant as preheater) 
The designed engine coolant and exhaust recovery ORC system can be operated under four designed conditions with different system layouts as illustrated in Fig. 1. The operational conditions of the four ORC system layouts are illustrated by the T-s diagram as shown in Fig. 2. The four ORC operational conditions are named as ORC_sim, ORCR_1, ORCR_2 and ORC_pre respectively representing as (a), (b), (c) and (d) in Fig. 2. The system layouts of ORC_sim and ORC_pre are both using the blue line in Fig. 1 (a). The system layouts of ORCR_1 and ORCR_2 are represented as orange line in Fig 1 (a) and Fig 1 (b), respectively.

Using ORC_sim as an example to describe the working conditions, the pump first pumps the working fluid from point 1 to point 2 , which is represented as an isentropic process. The heater 1 recovers the heat from the coolant energy while the heater 2 recovers the heat from the exhaust energy, which can be represented as process $2-4$ and process $4-6$, respectively. The evaporating temperature of the working fluid is designed at $80{ }^{\circ} \mathrm{C}$ to meet the heat source temperature of the coolant energy. The working conditions of the working fluid at the inlet of the expander start from the vapour saturated line to superheated region. The expansion process inside the expander is shown as line 6-7 as isentropic expansion process. The working fluid selected in the system is R245fa, which is a type of dry working fluids and can effectively prevent the ORC working fluid reaches two phase condition inside the expansion machine to protect the expander. The ORCR_1 recovers the exhaust heat from the expander from 7-7' as extra heat to preheat the working fluid from $2-2^{\prime}$ as shown in Fig. 2 (b). The exhaust heat from the expander in ORCR_2 is recovered to heat up the working fluid during the two phase change process from 3'-4 as presented in Fig. 2 (c). Fig. 2 (d) shows the designed operational conditions of the engine coolant and exhaust heat recovery ORC system using coolant energy as the preheat heat source, which means the working fluid is always in liquid phase during the heat up process provided from coolant heat source.

A small diesel fuelled ICE with the model number TF120M is selected in this study for the evaluation and comparison of the effects of using different engine coolant and exhaust heat recovery 
$181 \mathrm{~kW}$ rated power at $2400 \mathrm{RPM}$. The specifications of the engine are listed in Table 1.

\section{Table 1}

183 Engine specifications

\begin{tabular}{ll}
\hline Characteristic & Value \\
\hline Engine model & Yanmar TF120M \\
Engine type & Horizontal water-cooled, 4 cycle diesel engine \\
Engine Displacement $(\mathrm{L})$ & 0.638 \\
Number of cylinders & 1 \\
Cylinder bore $(\mathrm{mm})$ & 92 \\
Cylinder stroke $(\mathrm{mm})$ & 96 \\
Compression ratio & 17.7 \\
Combustion system & Direct Injection \\
Injection pressure $\left(\mathrm{kg} / \mathrm{cm}^{2}\right)$ & 200 \\
Max torque $(\mathrm{N} . \mathrm{m})$ & 43.35 at $1800 \mathrm{RPM}$ \\
Max Power $(\mathrm{kW})$ & 8.8 at 2400 RPM \\
\hline
\end{tabular}

For the evaluation of the performance of ORC system using coolant and exhaust energy, the two heat sources conditions require to be identified. Ringler et al. pointed out that the ratio of the recoverable heat from the coolant and exhaust energy of ICE ranges from 1.5 to 0.5 [28]. The

187 previous study of the authors and other researchers study also support that the point $[11,13,14,29-$

188 31]. Therefore, the recoverable wasted heat of this ICE can be plotted as Fig. 3, which has considered the real experimental results obtained from the YANMAR ICE under 10\%, 25\%, 50\%, 75\% and 100\% load at the engine rated speed $2400 \mathrm{rpm}[32]$ as listed in Table 2.

\section{Table 2}

192 Experimental results of the TF120M engine at rated speed under different load conditions [32]

\begin{tabular}{lllllll}
\hline $\begin{array}{l}\text { Engine } \\
\text { rated speed } \\
2400 \mathrm{rpm}\end{array}$ & $\begin{array}{l}\text { Engine } \\
\text { load }\end{array}$ & $\begin{array}{l}\text { Engine } \\
\text { power }(\mathrm{kW})\end{array}$ & $\begin{array}{l}\text { Fuel } \\
\text { consumption } \\
(\mathrm{kg} / \mathrm{h})\end{array}$ & $\begin{array}{l}\text { Exhaust gas } \\
\text { temp }\left({ }^{\circ} \mathrm{C}\right)\end{array}$ & $\begin{array}{l}\text { Recoverable } \\
\text { exhaust } \\
\text { energy }(\mathrm{kW})\end{array}$ & $\begin{array}{l}\text { Recoverable } \\
\text { coolant } \\
\text { energy }(\mathrm{kW})\end{array}$ \\
\hline & $10 \%$ & 0.990 & 0.705 & 236 & 1.36 & 1.56
\end{tabular}




\begin{tabular}{llllll}
$25 \%$ & 2.397 & 0.878 & 280 & 1.63 & 1.71 \\
$50 \%$ & 4.555 & 1.182 & 361 & 2.31 & 2.62 \\
$75 \%$ & 6.538 & 1.534 & 459 & 3.62 & 3.47 \\
$100 \%$ & 8.818 & 1.975 & 587 & 4.67 & 4.54 \\
\hline
\end{tabular}

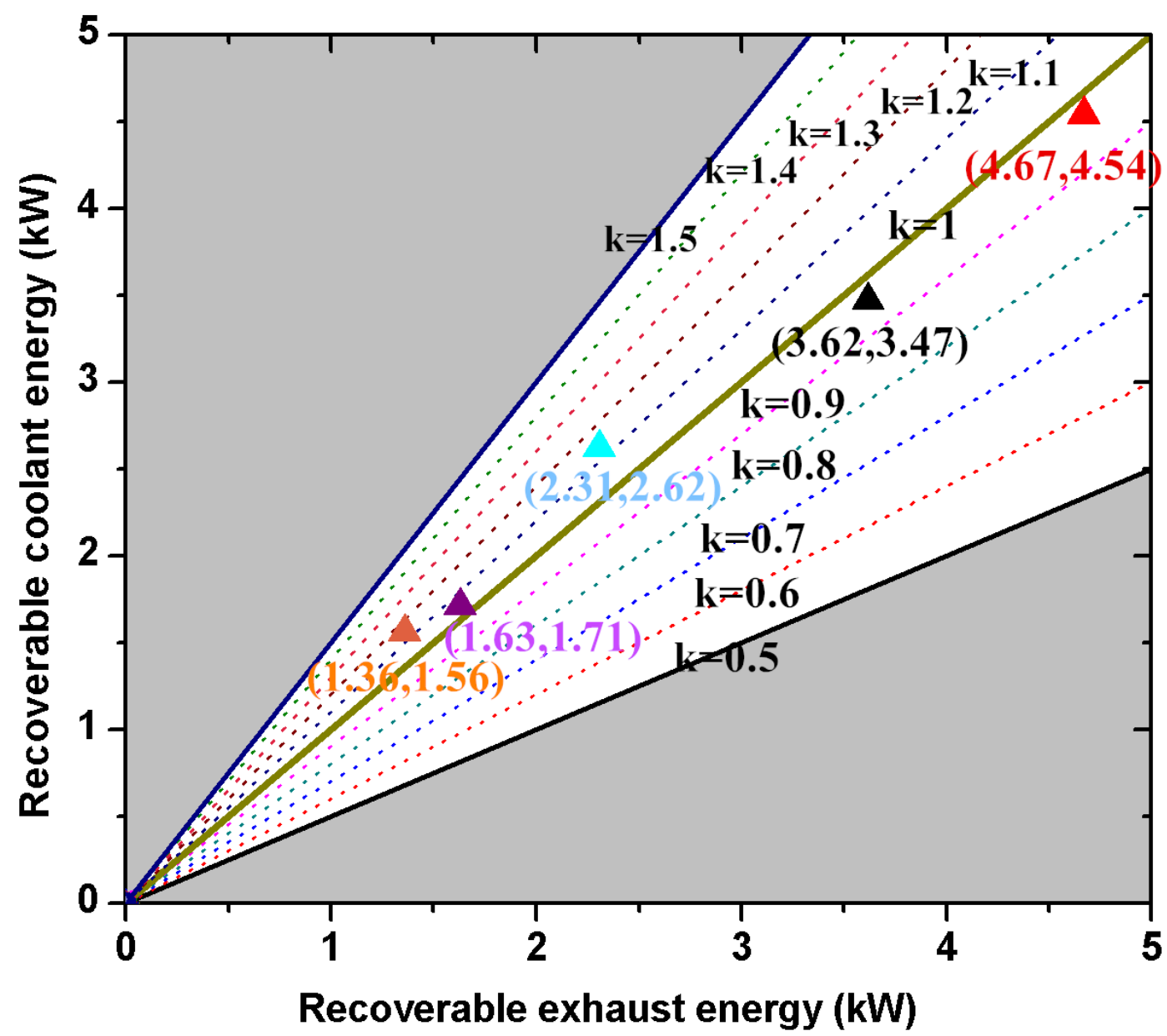

Fig. 3. Recoverable coolant and exhaust energy from a single cylinder Yanmar engine [33]

3. Simulation model and evaluation methods

\subsection{Description of the scroll expander model}

Geometric model of the scroll 
197 A geometric model of the selected scroll expander has been built to identify the physical parameters such as suction volume, exhaust volume, scroll turns and volume expansion ratio of the selected scroll expander to be used in the scroll expander introduced below. The expander used in this study is designed and manufactured by Air Squared with the model number E15H22N4.25 [34]. On the other hand the geometric study of the scroll expander can also reveal the relations between the fixed and orbiting scrolls during the real expansion processes.
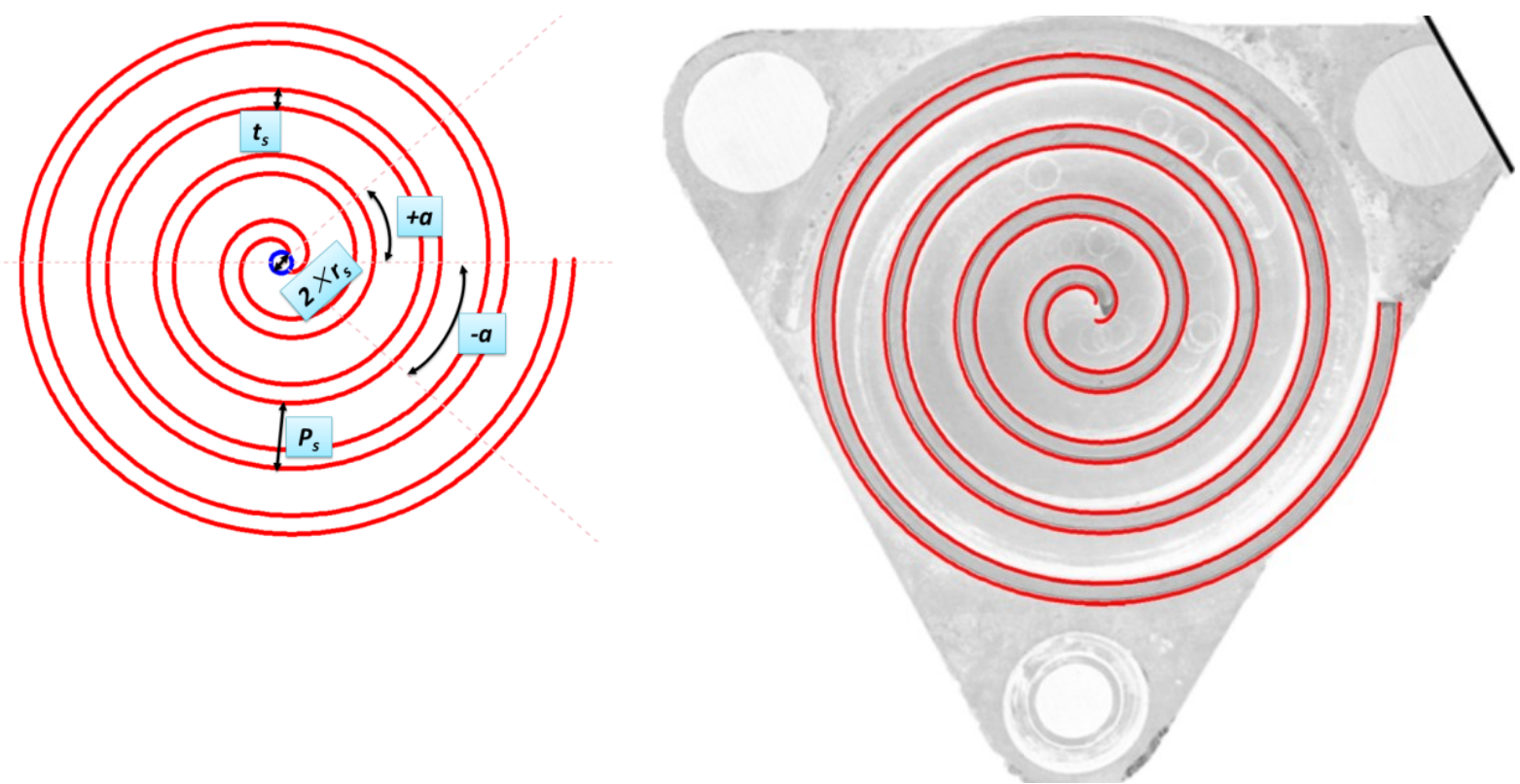

(a)

(b)

Fig. 4. Geometric study of the fixed scroll

(a) Geometric model of the fixed scroll, (b) Comparison of the geometric and real scroll

203 The scroll expander has been first disassembled for the measurement of the physical parameters including pitch of the scroll $P_{s}$, scroll blade thickness $t_{s}$ and height of the scroll $H_{s}$ as illustrated in Fig. 4 (b). The three parameters including radius of basic circle $r_{s}$, start angle of the involute $\alpha$ and radius of gyration of the orbiting scroll $R_{g y}$ are calculated by the following equations.

$$
\begin{aligned}
& P_{s}=2 \times \pi \times r_{s} \\
& t_{s}=2 \times r_{s} \times \alpha \\
& R_{g y}=\frac{1}{2} \times\left(P_{s}-2 \times t_{s}\right)
\end{aligned}
$$




$$
\begin{aligned}
& x=r_{s}[\cos (\phi+\alpha)+\phi \sin (\phi+\alpha)] \\
& y=r_{s}[\sin (\phi+\alpha)-\phi \cos (\phi+\alpha)]
\end{aligned}
$$

208

209

210

211

$V_{i}=\pi \times P_{s} \times\left(P_{s}-2 t_{s}\right) \times H_{s} \times\left(2 \times i-1-\frac{\theta}{\pi}\right)$

215 The exhaust volume per turn $V_{\text {exhaust }}$ of the scroll expander is calculated by equation (9), where $\theta_{\text {end }}$ represents the end of the angle of the expansion process and $N_{s}$ is the scroll turns.

$$
V_{\text {exhaust }}=\pi \times P_{s} \times\left(P_{s}-2 t_{s}\right) \times H_{s} \times\left(2 N_{s}-1-\frac{\theta_{\text {end }}}{\pi}\right)
$$

217 All the measured physical and calculated parameters are summarised and listed in Table 3. The expansion process inside the scroll expander under different crank angle can be illustrated as Fig. 5 .

\section{Table 3}

Parameters of the scroll

\begin{tabular}{lll}
\hline Name & Symbol & Value \\
\hline Scroll height & $H_{s}$ & $22.4 \mathrm{~mm}$
\end{tabular}


Scroll turns

Radius of gyration

Radius of the basic circle

Thickness of the scroll

Pitch of the scroll blade

Start angle of the involute

Exhaust volume of the expander per turn

Suction volume of the expander per turn

Internal volumetric expansion ratio

$\begin{array}{ll}N_{s} & 4 \\ R_{\mathrm{g} y} & 3.0 \mathrm{~mm} \\ r_{s} & 2.23 \mathrm{~mm} \\ t_{s} & 4.0 \mathrm{~mm} \\ P_{s} & 14.0 \mathrm{~mm} \\ \alpha & 51.43^{\circ} \\ V_{\text {exhaust }} & 41.38 \mathrm{~cm}^{3} \\ V_{\text {suction }} & 11.82 \mathrm{~cm}^{3} \\ r_{v_{-} \text {in }} & 3.5\end{array}$
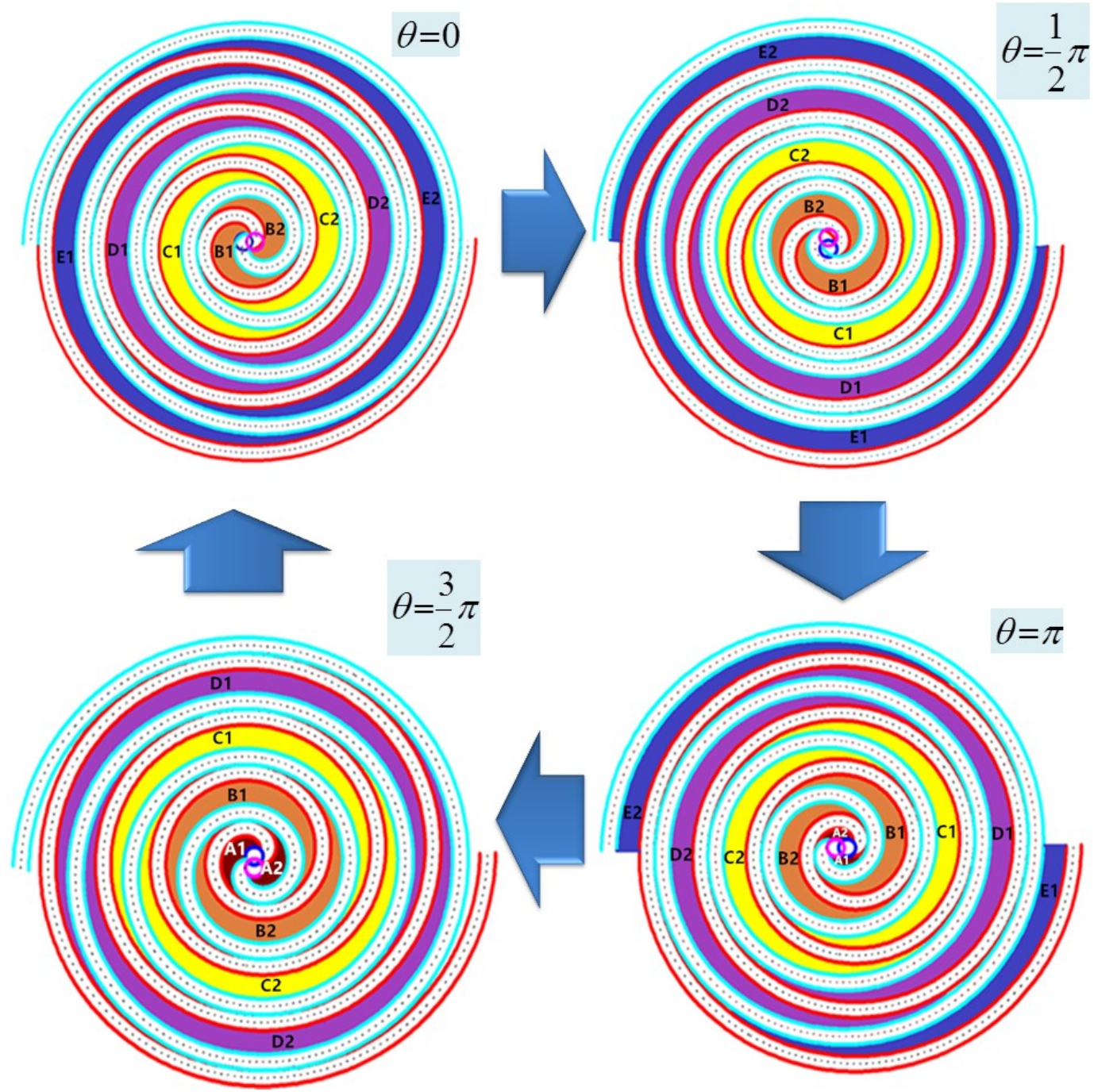

Fig. 5. Expansion process of the scroll expander under different crank angle 
226

\section{Description of the scroll expander model}

A semi-empirical scroll expander simulation model has been used in this study to predict the expander performance. The original scroll expander model was first proposed by Lemort et al. [36], which is a transformation of scroll compressor model. Several researchers apply the semi-empirical scroll expander to predict the performance of the scroll expander within specific operational ranges. The schematic diagram of the simplified semi-empirical scroll expander model is shown in Fig. 6.

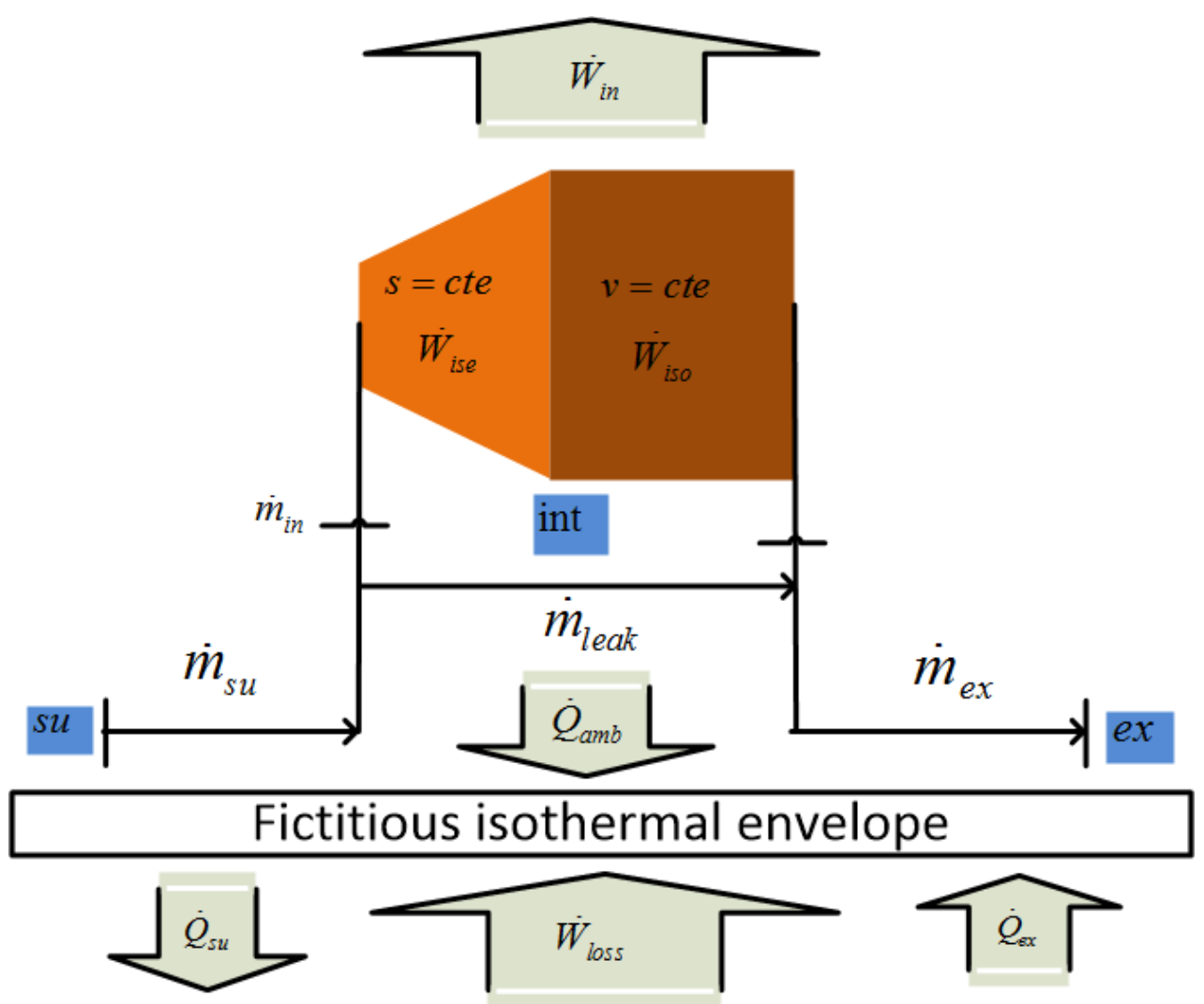

Fig. 6. schematic diagram of the scroll expander model

The expansion process of the scroll expander includes four steps:

233 (1) supply mass leakage from working point $s u$ to in , the supply mass flow rate $r_{\ldots}$ equals to the 234 internal mass flow rate $i_{\ldots . .}$ plus leaking mass flow rate $r_{\text {...... }}$; (2) the internal isentropic expansion 235 from point in to int ; (3) the isochoric expansion process inside the expander from int to ex $x_{1}$; (4) 
236 Mixing process at the expander exhaust when the internal leakage fluid mixes with the expansion

237 fluid

238 The internal expansion condition at point int is defined by the following equations.

$$
\begin{aligned}
& \gamma_{v_{-} \text {in }}=\frac{V_{\text {ex haust }}}{V_{\text {suction }}}=\frac{v_{\text {int }}}{v_{\text {su }}} \\
& P_{\text {int }}=f\left(v_{\text {int }}, S_{\text {su }}\right)
\end{aligned}
$$
during the isentropic and isochoric process from the expander as illustrated in equation (6).

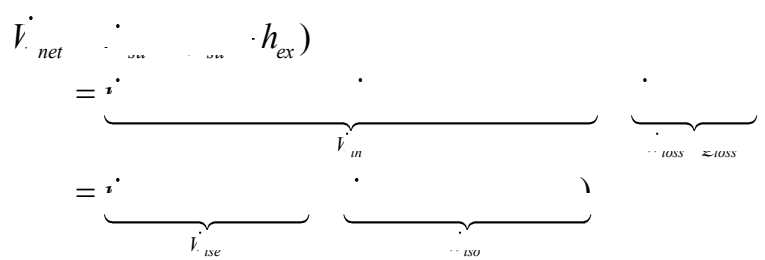

241 The rotational speed of the expander can be calculated by

$r_{\ldots} \quad v_{s u}: \frac{r_{\text {suction }}}{60 \times v_{s u}}$

The overall energy loss $q_{\text {loss }}$ of the scroll expander during the expansion process is calculated by equation (8). The calculation of the overall energy loss is defined by the pressure ratio of the inlet and outlet conditions. The experimental results conducted by other researchers are used to determinate the overall energy loss of this scroll expander. All of the collected experimental results from the reported papers are all using the same scroll expander and R245fa as the working fluid in the ORC system.

247 The collected experimental data used in the scroll expander simulation model can be found in Table 4.

·

$\gamma_{p}=\frac{P_{s u}}{P_{e x}}$

$q_{\text {loss }}=4.1911 \times \ln \left(\gamma_{p}\right)-0.4389$ 
249 Collected experimental data using the selected scroll expander and R245fa in ORC [17, 19, 37]

\begin{tabular}{llllllll}
\hline No & $\begin{array}{l}\text { Inlet } \\
\text { temperature } \\
(\mathrm{oC})\end{array}$ & $\begin{array}{l}\text { Outlet } \\
\text { temperature } \\
(\mathrm{oC})\end{array}$ & $\begin{array}{l}\text { Scroll } \\
\text { expander } \\
\text { rotational } \\
\text { speed } \\
(\mathrm{RPM})\end{array}$ & $\begin{array}{l}\text { Mass } \\
\text { flow } \\
\text { rate } \\
(\mathrm{kg} / \mathrm{s})\end{array}$ & $\begin{array}{l}\text { Inlet } \\
\text { pressure } \\
(\mathrm{bar})\end{array}$ & $\begin{array}{l}\text { Expansion } \\
\text { ratio }(-)\end{array}$ & $\begin{array}{l}\text { Expander } \\
\text { isentropic } \\
\text { efficiency } \\
(\%)\end{array}$ \\
\hline $1[17]$ & 127.3 & 84.4 & 3496 & 0.057 & 11.97 & 10.65 & 58.8 \\
$2[17]$ & 126.2 & 83.6 & 3490 & 0.053 & 11.14 & 9.92 & 61.98 \\
$3[17]$ & 100 & 60 & 3500 & 0.050 & 8.4 & 7.5 & 71.0 \\
$4[17]$ & 96.1 & 58.9 & 3415 & 0.047 & 8.82 & 6.52 & 72.5 \\
$5[17]$ & n. a & n. a & n. a & n. a & n. a & 6.1 & 77.5 \\
$6[19]$ & 89.7 & 38.4 & n. a & 0.052 & 9.95 & 4.58 & 84.9 \\
$7[37]$ & 75 & n. a & 3600 & 0.018 & 4.34 & 3.1 & 85 \\
\hline
\end{tabular}

The isentropic efficiency calculated from the simulation model under different supply and exhaust

251 pressure conditions are plotted in Fig. 7. The experimental results conducted and reported by other

252 researcher are illustrated by the red triangle symbol, which shows good agreement with the simulation 253 results.

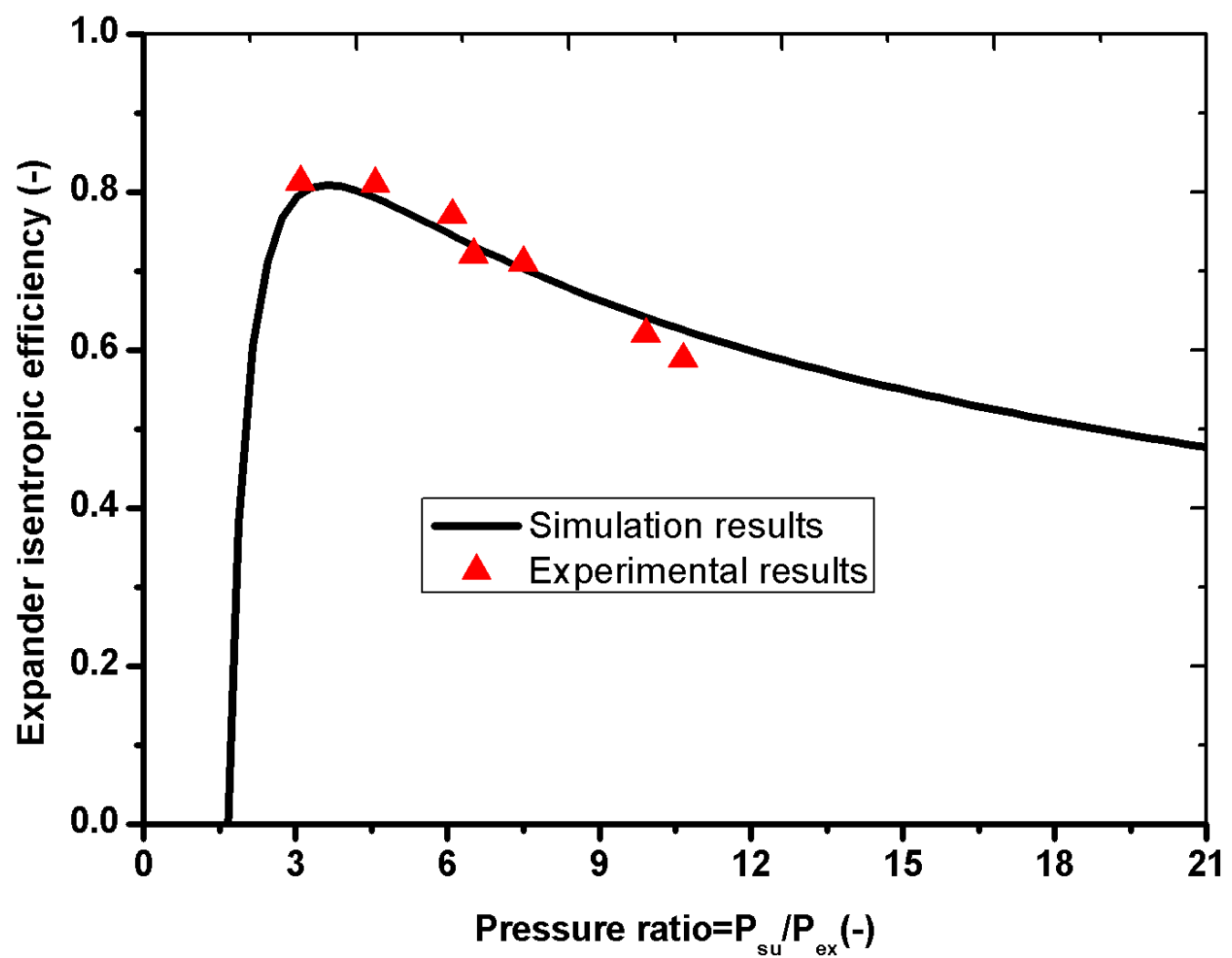

Fig. 7. Comparison of simulation and experimental results 


\subsection{Evaluation methods of the ORC system}

For the evaluation of the performance of different engine coolant and exhaust recovery ORC layouts using a selected scroll expander, the thermodynamic models of different ORC systems have been built and coded in Engineering Equation Solver [38] to obtain the fluid properties under different conditions. The heat transfer efficiency of the heater exchangers $\left(\eta_{\text {Heater } 1}, \eta_{\text {Heater } 2}, \eta_{r}\right)$ and the pump performance in the ORC system. The equations of the simulation model are described as follows:

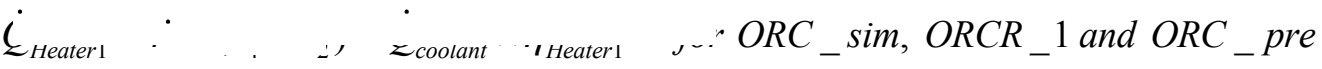

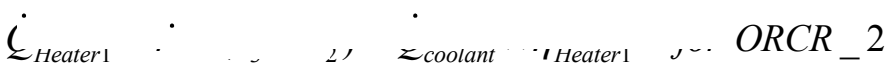

262 Heat provided to Heater 2 can be written as,

$$
\dot{\varepsilon}_{\text {Heater } 2}
$$$$
\text { exnaust }
$$

Heater 2

The work consumed by the pump is calculated by,

$$
\dot{V} \cdot \quad \cdot \quad) / \eta_{p}
$$

$\eta_{r}=r^{\cdot}$

$$
\dot{\varepsilon}_{\max } \quad, \text {, when } \mathrm{T}_{7}=\mathrm{T}_{2}
$$

265 The regenerated heat from the exhaust of the expander in the ORCR_2 is calculated by the

following equation

$$
\begin{aligned}
& \eta_{r}=\dot{r} \\
& \dot{\varepsilon}_{\max } \quad, \quad, \text {, when } \mathrm{T}_{7}=\mathrm{T}_{3}
\end{aligned}
$$

The calculation of isentropic efficiency of the scroll expander is defined in equation (16), where 

equation (17).

$$
\begin{aligned}
& \eta_{\text {isen }}=\frac{\dot{V}_{\text {net }}}{\left.\dot{r} \ldots \ldots \cdot h_{e x_{-} s}\right)}
\end{aligned}
$$

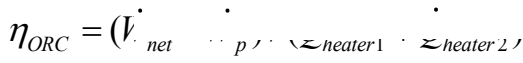

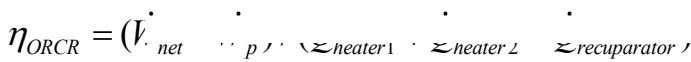

271 In order to evaluate the effects of integrating the ORC coolant and exhaust heat recovery system

272 on ICE. The overall effective energy efficiency of the ICE and ICE integrated with ORC are defined

273 by equation (18) and (19), respectively.

$$
\begin{aligned}
& \eta_{I C E}=\frac{\dot{V}_{o}}{\dot{r}} \\
& \eta_{\text {ICE }+O R C}=\frac{\dot{V_{0}} \cdot \dot{U K C}_{p}}{\dot{r}}
\end{aligned}
$$
set at $43400 \mathrm{~kJ} / \mathrm{kg}$ in this study.

$$
\begin{aligned}
& B S F C_{I C E}=\frac{\dot{r}}{\dot{V}} \cdot{ }_{b} . . .
\end{aligned}
$$

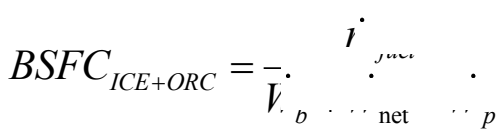


In order to obtain an overview of the engine coolant and exhaust recovery ORC system using different layouts, the parametric studies on the system performance are conducted and the parametric data of different ORC system are compared. Because the engine coolant temperature ranges from 80 to $100{ }^{\circ} \mathrm{C}$, the evaporating temperature in the ORC systems (ORC_sim, ORCR_1 and ORCR_2) is set at $80{ }^{\circ} \mathrm{C}$ in order to fully recover the coolant heat during the phase change process of the working fluid. ORC_pre applies the coolant energy as the preheater. The designed evaporating temperature of R245fa in ORC_pre is therefore set at the saturated temperature of the maximum designed scroll expander, which are $104.4{ }^{\circ} \mathrm{C}$ and 13.8 bar, respectively. Considering the real on road application for the vehicle, the lowest condensation temperature can be provided by the radiator is normally around $40{ }^{\circ} \mathrm{C}$. The ORC condensation temperature is therefore set at $40{ }^{\circ} \mathrm{C}$ in this study.

\subsection{Effects of superheating temperature using different ORC layouts under} engine rated power condition with different superheating temperature under the engine rated power condition. The thermal efficiency, power output, mass flow rate of the fluid, rotational speed of the scroll expander, condenser loads and pump work of different ORC systems are compared. The results are plotted in Fig. 8 .

The results indicated the thermal efficiency of ORC_pre, ORCR_1 and ORCR_2 slightly increase with the increase of superheating temperature and the efficiency of ORC_sim is quite stable (about 0.062) under different superheating temperature as shown in Fig.8.(a). When the supply fluid temperature ranges between $80-110{ }^{\circ} \mathrm{C}$, the overall efficiency of ORCR_2 is lower than that of ORC_sim because the exhaust temperature of the scroll expander within these operational conditions is lower than the coolant temperature. When the recuperator is added in the ORC system, the overall efficiency of ORCR_1 is always higher than that of ORCR_2. 
The analysis of the power output of the ORC_sim and ORC_pre indicates that the change of superheated temperature has limited effects on the power performance on these two systems as illustrated in Fig.8.(b). The average produced power from ORC_sim and ORC_pre under the designed conditions are $0.59 \mathrm{~kW}$ and $0.5 \mathrm{~kW}$, respectively. Although the overall system efficiency of ORC_pre is higher than that of other three ORC systems, the power from ORC_pre is always lower than the ORC cycles designed to fully recover coolant energy, which means the idea of fully recovering coolant heat from the ICE to form a single loop ORC system will sacrifice the system efficiency but can generate more power.

The mass flowrate of the four ORC systems are all decreased with the increase of expander inlet temperature, which indicate the tendency of the pump power should have the same relationship with expander inlet temperature as indicated in Fig.8 (c) and (f). Although the mass flowrate of ORC_pre is lower than that of other three ORC systems, the required pump work for ORC pre is clearly higher than other systems, which is caused by the high evaporating pressure of ORC_pre.

The increase of superheated inlet temperature has limited influence on the rotational speed of the scroll expander in ORC_sim and ORC_pre, which is about $3200 \mathrm{rpm}$ and $1000 \mathrm{rpm}$, respectively. The increase of superheated inlet temperature will lead to the increase of scroll expander rotational speed in ORCR_1 and ORCR_2 as shown in Fig. 8 (d). For the on road vehicle application, the requirement of dumped heat from the radiator is extremely important to study. The high demand of heat dumped radiator system requires large radiator cooling system, which is clearly not desirable for on road vehicle application. The radiator serves as the condenser in ORC system when applies the heat recovery system for vehicle application. The results indicates the single loop ORC system designed to fully recover coolant and exhaust energy (ORC_sim) without using recuperator has the advantage on the low requirement of dumped heat from the condenser (around $6.8 \mathrm{~kW}$ under engine rated power condition) as shown in Fig. 8 (e). 


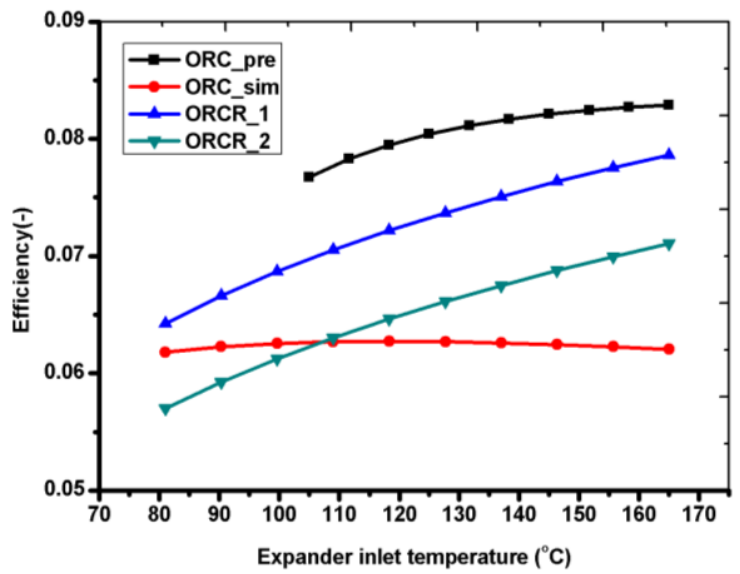

(a)

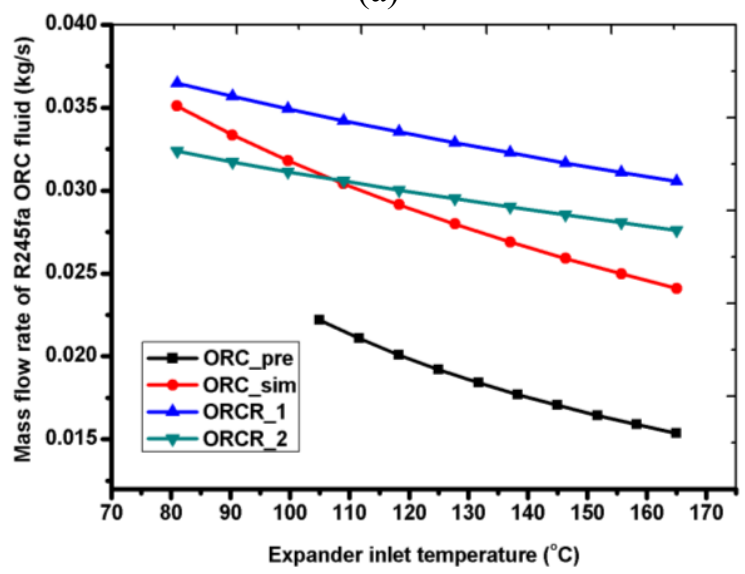

(c)

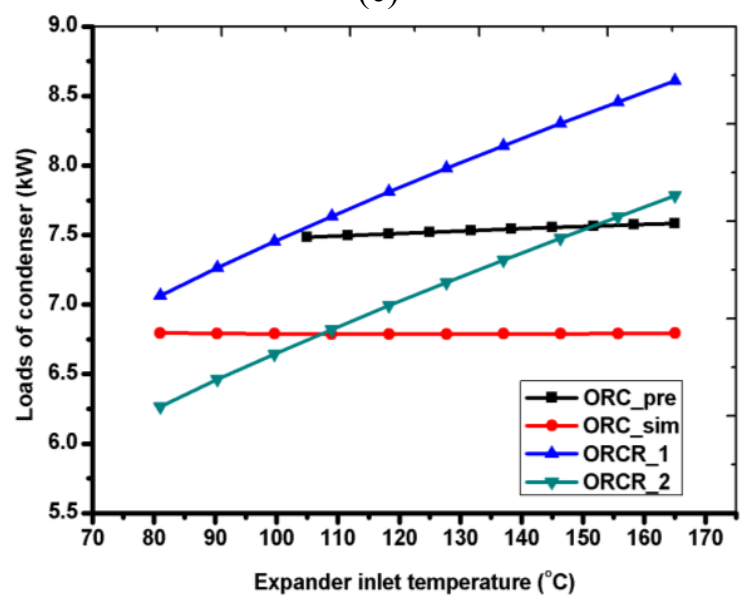

(e)

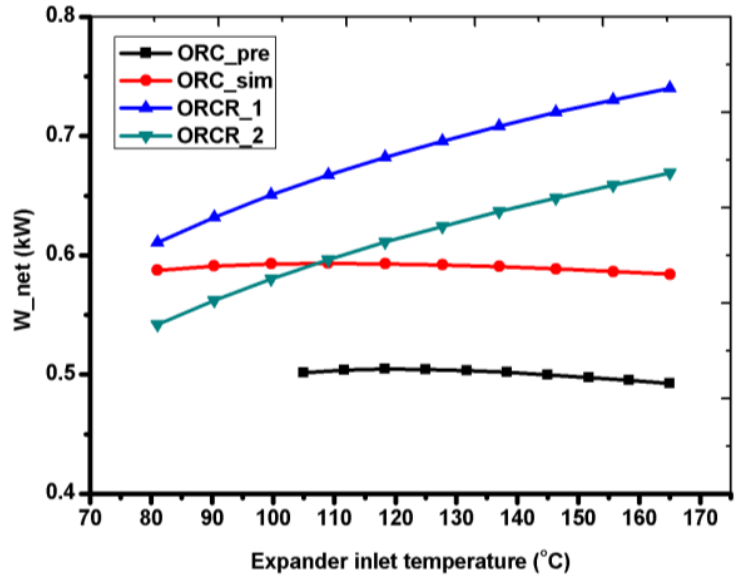

(b)

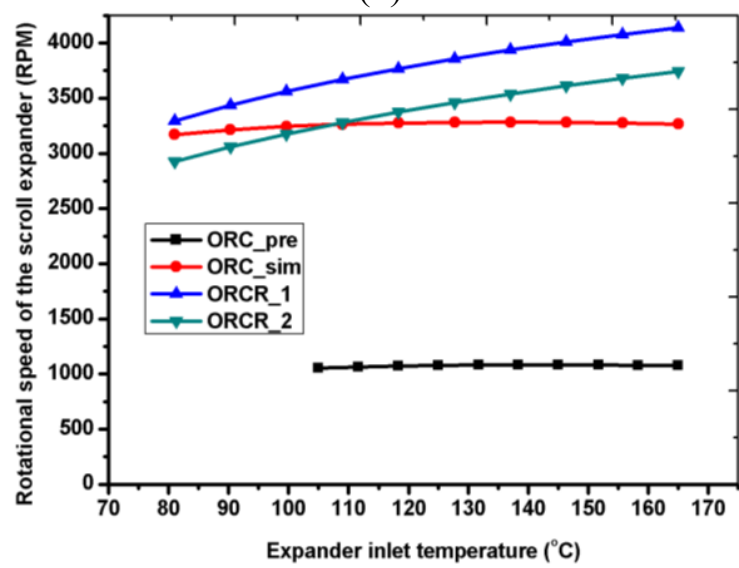

(d)

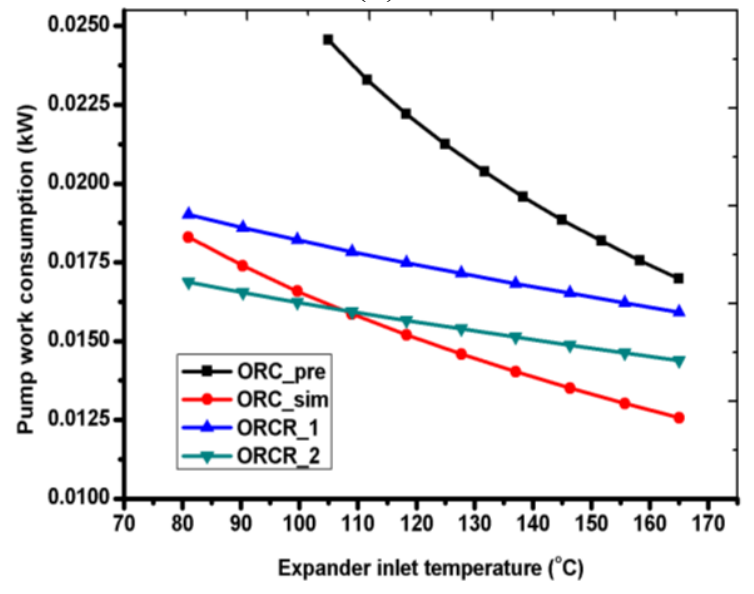

(f)

Fig. 8. Effects of superheated temperature on the ORC performance at engine rated power condition (a) ORC system efficiency; (b) scroll expander net power output ;

(c) fluid mass flowrate; (d) Rotational speed of the scroll expander;

(e) condenser loads; (f) pump work under different expander inlet temperature 

previously. In order to have an overview of different coolant and exhaust recovery ORC performance,

331 the parametric investigation has been conducted under different coolant and exhaust heat conditions

332 of the selected single cylinder Yanmar engine. The net power output, rotational speed of the scroll expander and condenser loads of four different coolant and exhaust ORC systems are calculated and compared under the ORC superheated inlet temperature at $150^{\circ} \mathrm{C}$, which is within the optimal working conditions of the four ORC system as previously discussed.

\section{Evaluation of generated power from different ORC systems}

The power output from four engine coolant and exhaust ORC systems are compared and the results are plotted in Fig. 9. Under the designed ORC operational conditions, the results of ORC_sim, ORCR_1 and ORCR_2 suggest the power produced from ORC system using recuperator can produce more power than the system without recuperator. The regeneration of exhaust heat from expander is suggested to be located between the fluid pump and coolant heater exchanger. The ORC_pre shows better power performance than ORC_sim, when the ratio of engine coolant and exhaust heat is between 0.5-0.7 as shown in Fig. 9 (a) and (d). The power produced from ORC_pre has linear relationship with the engine exhaust heat because the coolant energy from the engine cannot be fully recovered. As described in section 2 and illustrated in Fig. 2, the ORC_pre and ORC_sim deploy the same system layout. The ORC_sim can be easily modified as ORC_pre by changing the evaporating condition of the fluid, when the ratio of coolant and exhaust heat ranges from 0.5 to 0.7 . 


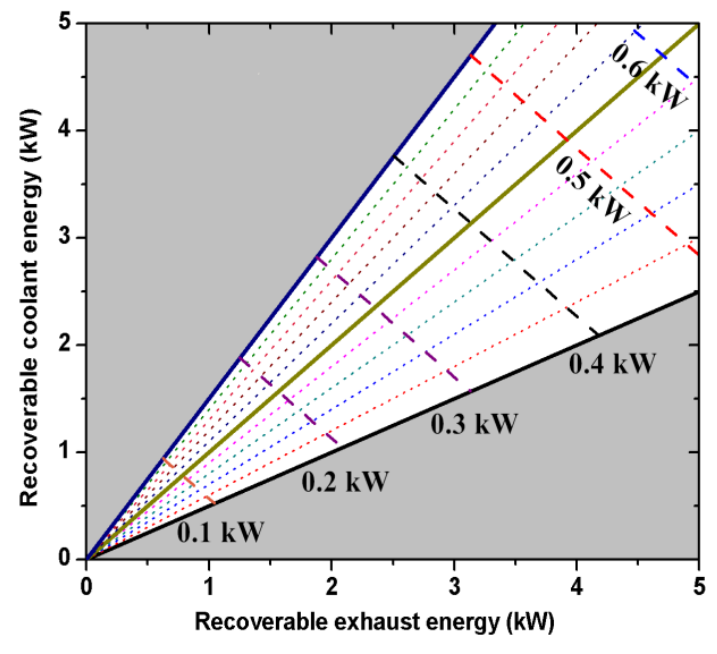

(a)

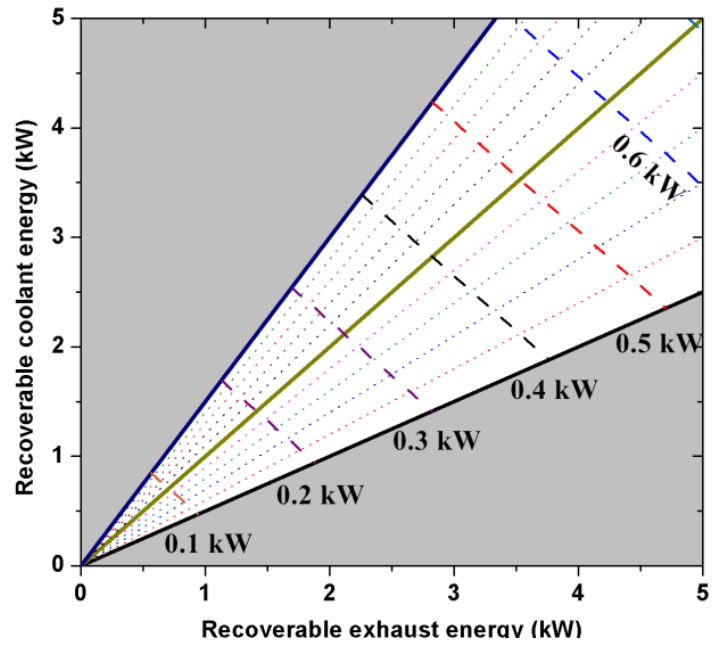

(c)

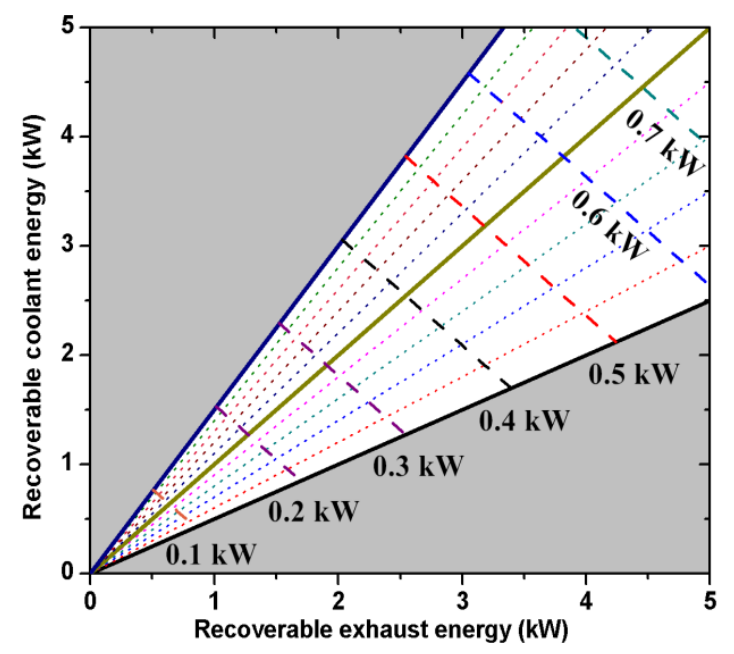

(b)

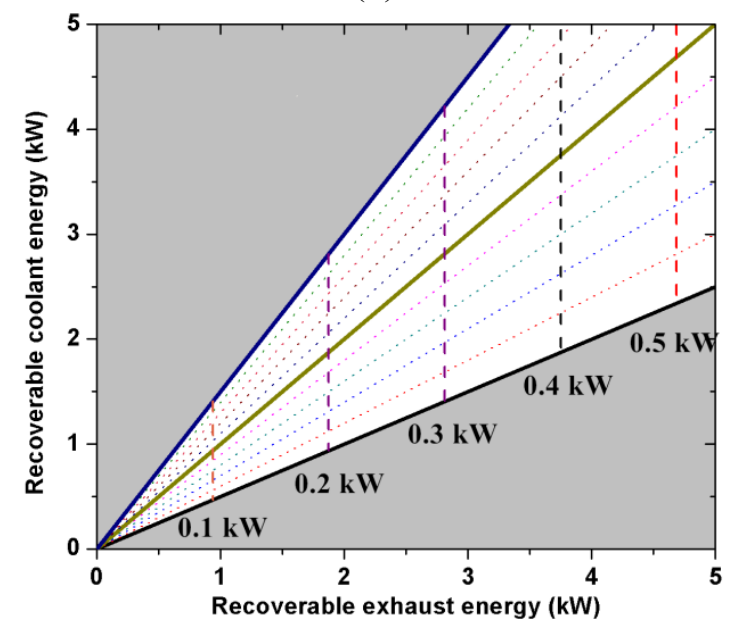

(d)

Fig. 9. ORC net power output under different coolant and exhaust heat conditions (a) ORC_sim; (b) ORCR_1; (c) ORCR_2; (d) ORC_pre

\section{Evaluation of rotational speed of the scroll expander}

The rotational speed of the scroll expander under different engine coolant and exhaust heat conditions of the single cylinder engine has been studied. A proper selection of transmission system can convert the power from the scroll expander into mechanical work or the mechanical work from the expander can be used to produce electricity by connecting the expander with an electrical generator. The results as drawn in Fig. 10 suggest the rotational speed of the scroll expander in the designed four engine coolant and exhaust heat recovery ORC systems can be lower than $4000 \mathrm{rpm}$, which means the scroll expander can be potentially used to directly connect with conventional 

relatively low rotational speed of the scroll expander is required for specific applications.

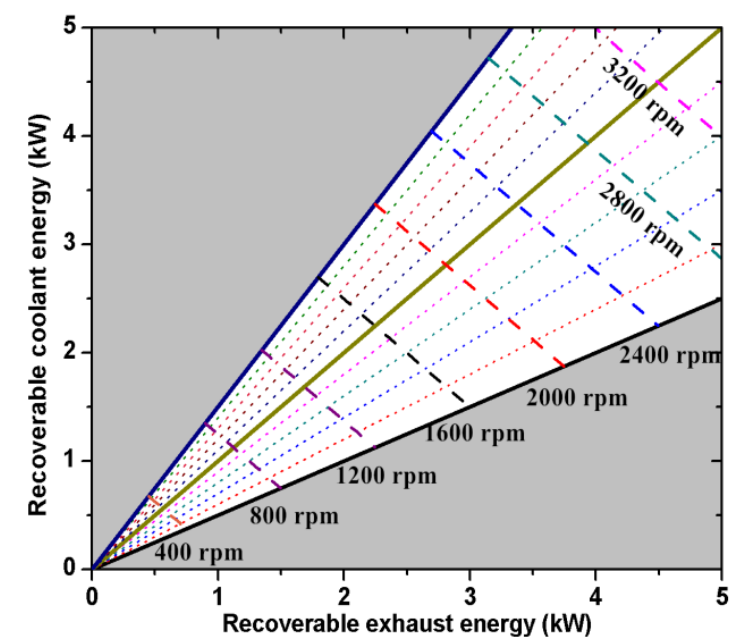

(a)

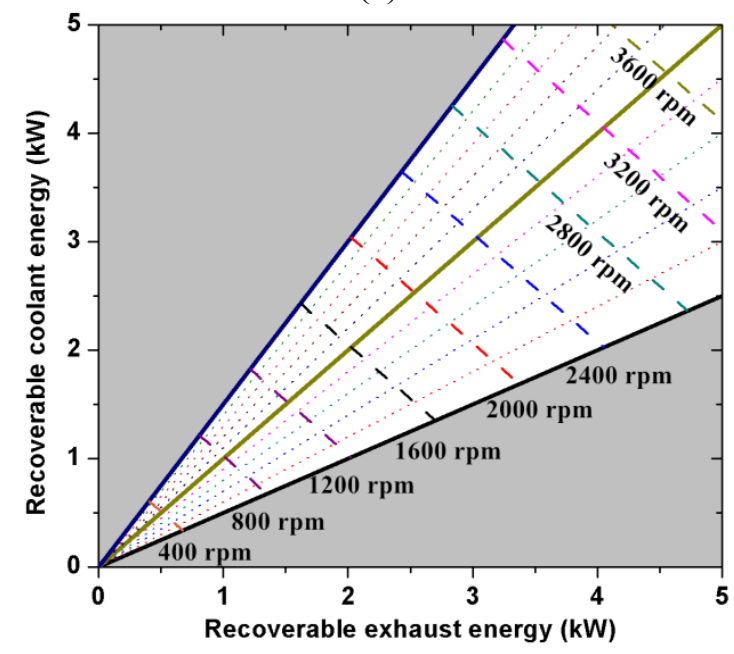

(c)

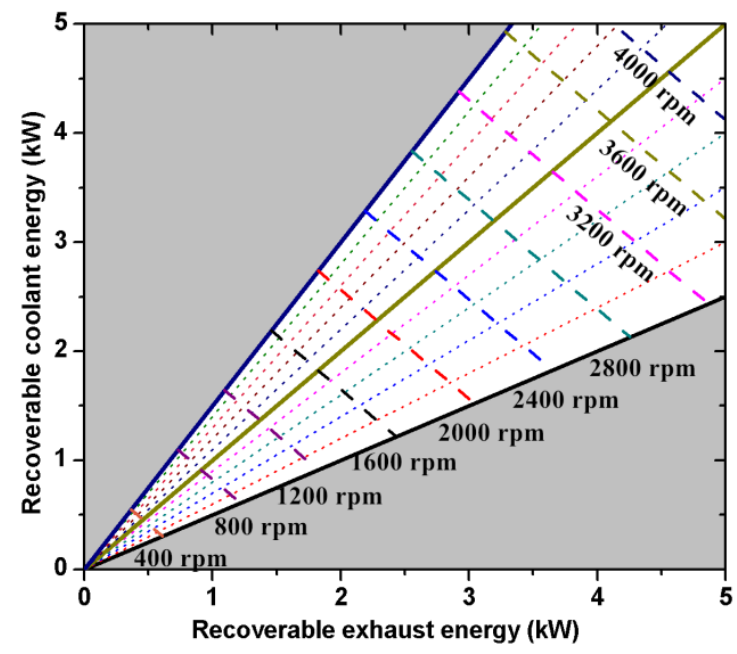

(b)

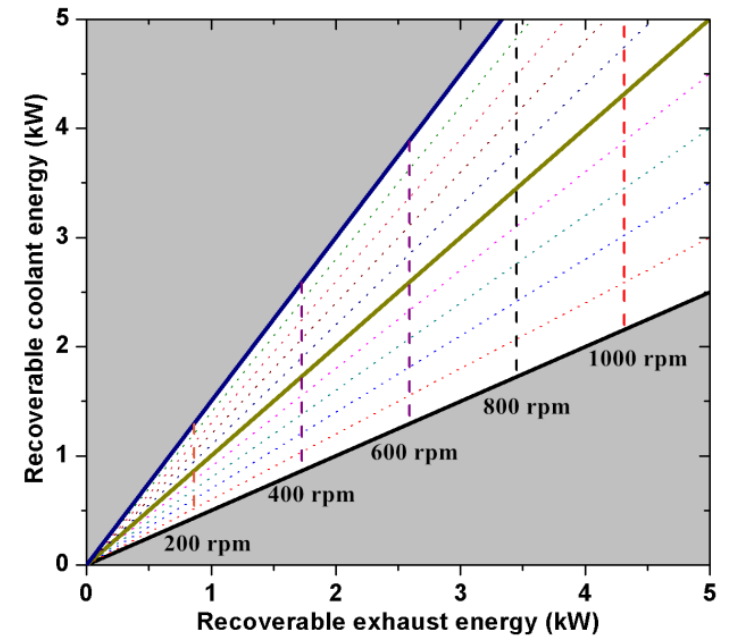

(d)

Fig. 10. Scroll expander rotational speed under different coolant and exhaust heat conditions ORC_sim; (b) ORCR_1; (c) ORCR_2; (d) ORC_pre

\section{8 \\ Evaluation of the required heat dumped loads of condenser}

The study conducted on the heat load requirements of the condenser suggested, under the same designed ORC operational conditions and the simple ORC system layout for fully recovery of engine coolant and exhaust heat has the lowest heat load compared with other three ORC systems as shown in Fig. 11. When the recuperator in ORC system is located between the two heat sources, the requirement on the condenser to dump unrecoverable heat is the highest among the four coolant and 
exhaust heat recovery ORC systems, which is clearly not desirable for vehicle application. In summary, results suggest the recuperator can potentially improve the power performance of simple layout ORC system for engine coolant and exhaust system and will increase the rotational speed of the scroll expander under the same operational conditions. The system performance of ORCR_2 has almost no advantages when compared with that of ORCR_1, which means the recuperator is suggested to be located between fluid pump and coolant heater.

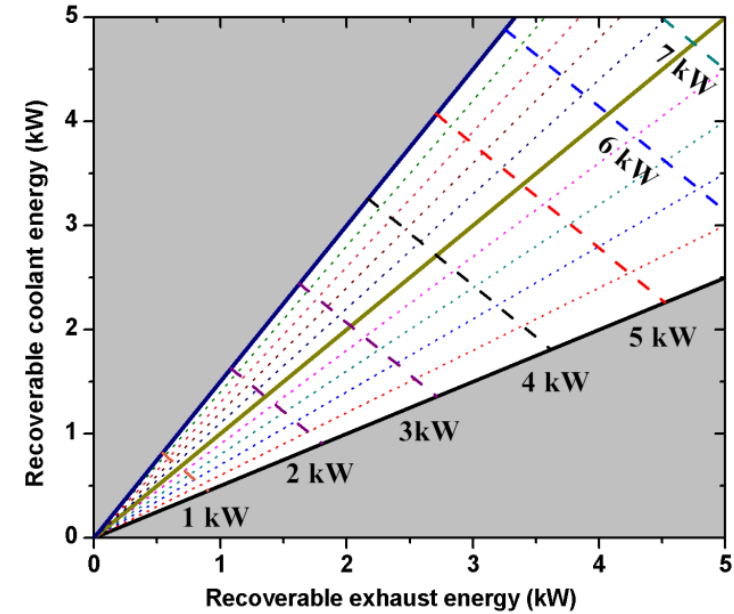

(a)

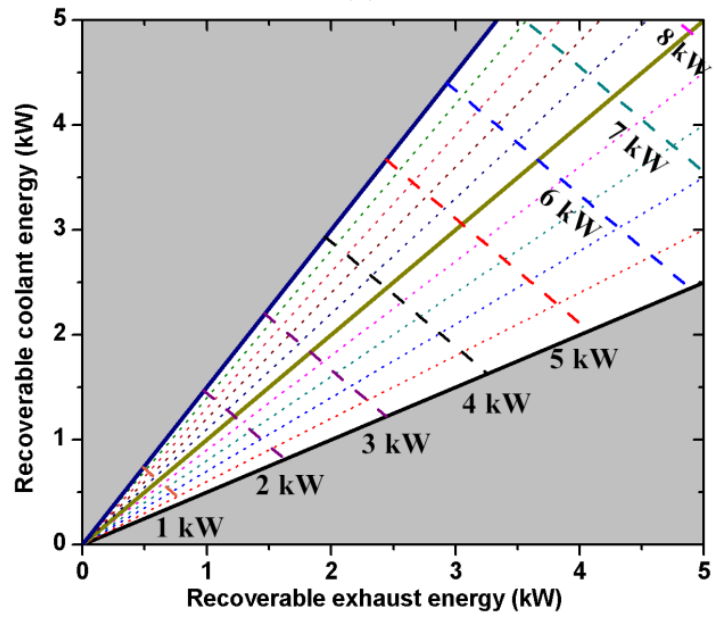

(c)

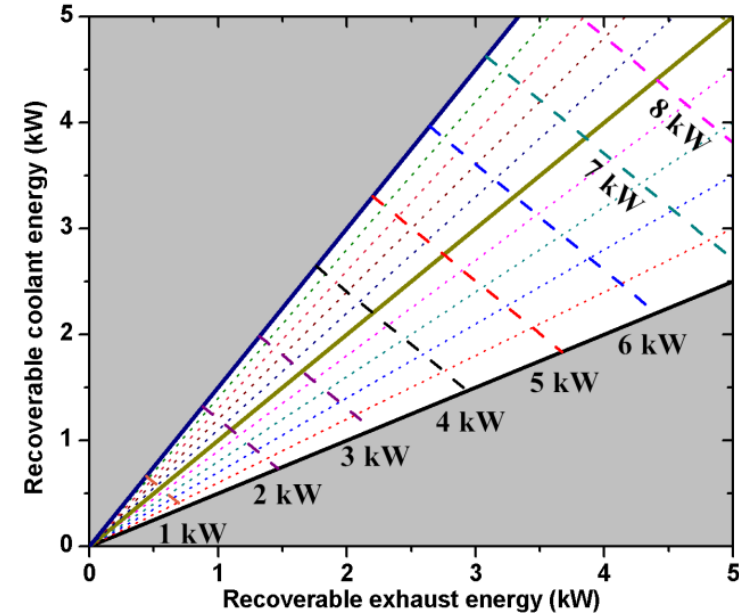

(b)

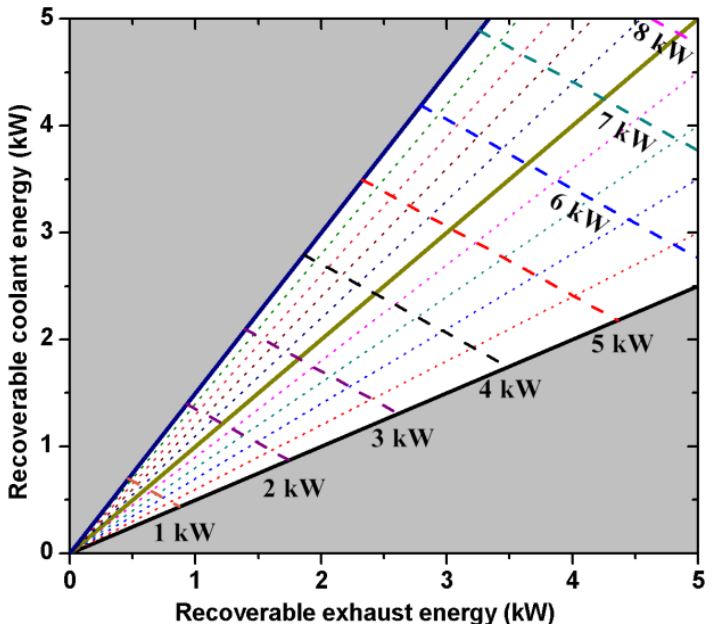

(d)

Fig. 11. Condenser loads of the ORC under different coolant and exhaust heat conditions ORC_sim; (b) ORCR_1; (c) ORCR_2; (d) ORC_pre

\subsection{Effects of using coolant and exhaust recovery ORC systems on the}


The influence of using designed engine coolant and exhaust recovery ORC systems on the ICE

373 performance are evaluated under five engine real operational conditions as listed in Table 2. The

374 brake specific fuel consumption (BSFC) and overall effective energy efficiency of the ICE with and

375 without using different ORC systems are compared. The performance of ORCR_2 has not been

376 included in the analysis of this section, because the ORCR_1 with similar system layout has better

377 overall system performance than that of ORCR_2 such as higher power output, increased thermal

378 efficiency and lower requirement of condenser load.

\section{BSFC improvement under different engine loads at engine rated speed}

The BSFC of the diesel fuelled Yanmar engine with and without using three ORC systems under five difference engine loads $(10 \%, 25 \%, 50,75 \%$ and $100 \%)$ at rated speed are compared and drawn in Fig. 12 (a). The BSFC reduction ratio of using the designed coolant and exhaust heat recovery ORC systems has been drawn in Fig. 12 (b), which suggest by using the heat recovery system can achieve better overall fuel efficiency in engine part load conditions. The BSFC reduction ratios of ICE+ORC_sim, ICE+ORCR_1 and ICE+ORC_pre under 10\% engine load at rated speed are $15.5 \%$, $18.5 \%$ and $12.4 \%$, respectively. At the engine rated power condition, the BSFC reduction ratios of the three ORC systems are $6.1 \%, 7.4 \%$ and $5.2 \%$.

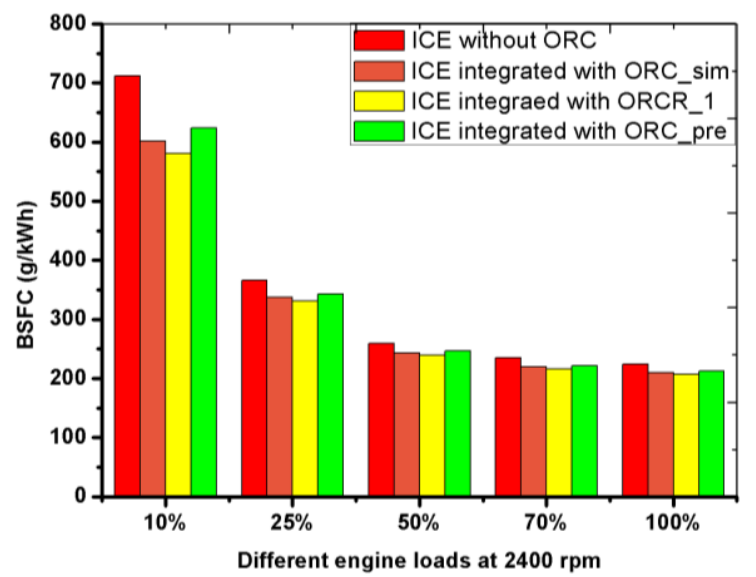

(a)

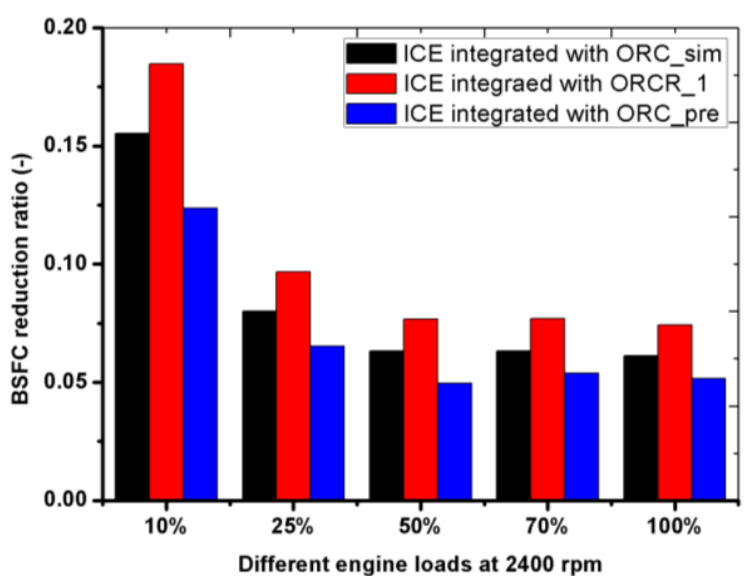

(b)

Fig. 12. Effects on BSFC at engine rated speed under different loads 

systems

The overall effective energy efficiency of ICE and ICE using different coolant and exhaust recovery ORC systems has been calculated by equation (18) and (19). The results are drawn in Fig. 13 (a). The ORCR_1 has the best overall energy efficiency improvement on the ICE among the three ORC systems. The improvement of the overall energy efficiency by using different ORC systems has been calculated and results have been drawn in Fig. 13 (b). By integrating ORC_Sim, ORCR_1 and ORC_pre with the ICE, the overall energy efficiency of the system can be improved by $6.5 \%, 8.0 \%$ and $5.4 \%$ under engine rated power condition. The maximum improvements of overall energy efficiency under the selected engine conditions are about $18.4 \%, 22.7 \%$ and $14.1 \%$, when the ICE is under $10 \%$ load at rated engine speed.

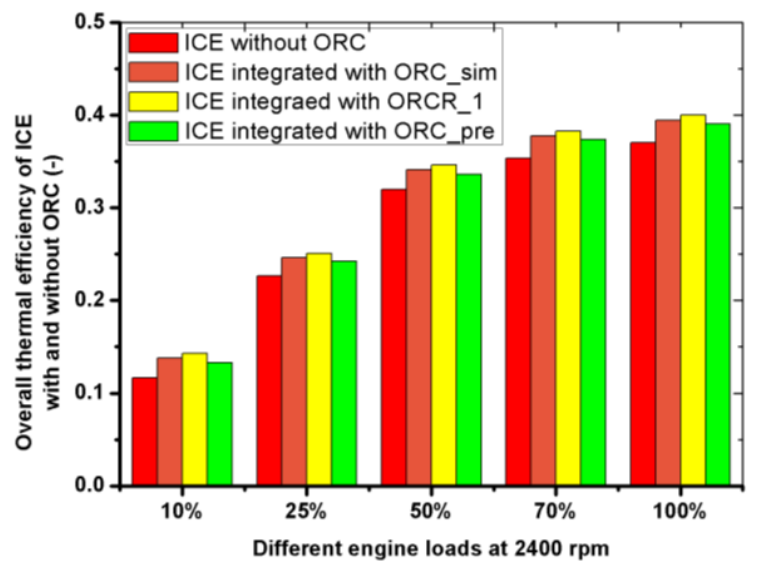

(a)

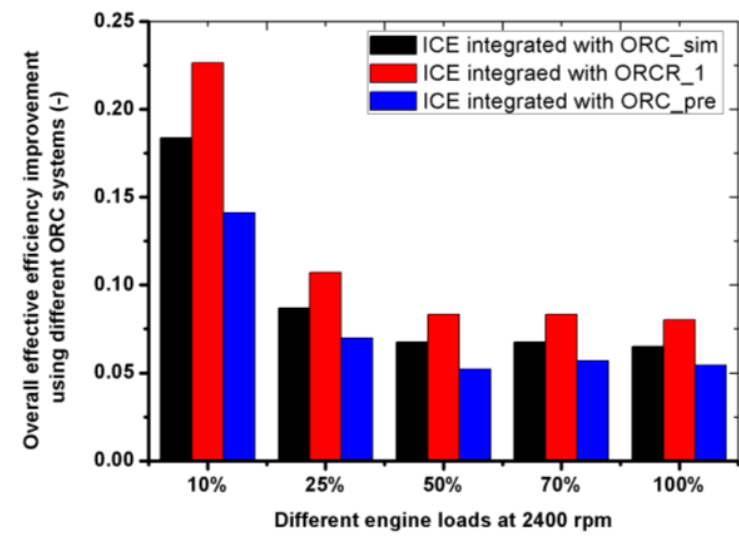

(b)

Fig. 13. Overall energy efficiency of the ICE with and without different ORC layouts under different loads at engine rated speed

\section{Conclusions}

In this study, four different small scale ORC waste heat recovery systems using a targeted scroll expander as the expansion machine to recovery both coolant and exhaust energy from a $6.8 \mathrm{~kW}$ engine have been reported. The four ORC system performances have first been studied under the engine rated condition to identify the optimal superheating temperature ranges. The parametric study of different coolant and exhaust recovery ORC systems are conducted to provide and compare the 
parametric data of four ORC systems. The effects of using the designed ORC systems to recover coolant and exhaust energy from ICE on the engine performance showing as the potential saving of fuel consumption and overall energy efficiency improvement are investigated under five different engine loads conditions. The conclusion drawn from this study are summarised as follows,

- When the super heating temperature increase from $80{ }^{\circ} \mathrm{C}$ to $160{ }^{\circ} \mathrm{C}$, The efficiency of ORC_sim is quite stable at $6.2 \%$ with the increase of superheating temperature and the efficiency of other three single loop coolant and exhaust recovery ORC systems are slightly improved. When the super heating temperature is lower than $110{ }^{\circ} \mathrm{C}$, the efficiency of ORCR_2 is lower than that of ORC_sim, because the exhaust temperature from the expander is lower than the coolant temperature leading to the low overall energy efficiency of the ORCR_2 system.

- The change of superheating temperature has limited effects on power performance of ORC_sim and ORC_pre. The average generated power from ORC_sim and ORC_pre are about $0.59 \mathrm{~kW}$ and $0.5 \mathrm{~kW}$. The results indicated the efficiency of ORC_pre using coolant energy as preheater is higher than that of other three ORC systems, but the power performance of ORC_pre is the worst among the four candidate coolant and exhaust heat recovery ORC systems. The idea of fully recovering coolant heat from the ICE to form a single loop ORC system can potentially produce more power, although the ORC energy efficiency can be slightly reduced.

- The scroll expander rotational speed of ORC_sim and ORC_pre respectively are stable about $3200 \mathrm{rpm}$ and $1000 \mathrm{rpm}$, when the superheated temperature ranges between 80 and $160{ }^{\circ} \mathrm{C}$. The designed single loop ORC system to fully recover coolant and exhaust energy from ICE without using recuperator (ORC_sim) has the advantage of low demand of dumped heat from condenser (around $6.8 \mathrm{~kW}$ under engine ratated power condition), which is desirable to be selected for on road vehicle application. 
- The parametric study of four ORC systems suggest ORC_pre can produce more power than ORC_sim, when the ratio of engine coolant and exhaust ranges from 0.5 to 0.7 . The power generated from ORC_pre has linear relationship with engine exhaust energy, which means the coolant energy cannot be fully recovered by this type of ORC system. The ORC_sim can potentially be modified into ORC_pre to produce more power under the coolant and exhaust ratio from 0.5 to 0.7 . When the recuperator is located between the coolant heater and exhaust heater, the demand of rejected heat from the condenser is relatively higher than that of other three ORC systems under the same operational conditions, which is not desirable for vehicle application.

- The analysis on the BSFC and overall effective energy efficiency of engine performance under five different engine loads at rated speed suggest the BSFC reduction ratio of using ICE+ORC_sim, ICE+ORCR_1 and ICE+ORC_pre under 10\% engine load at rated speed are $15.5 \%, 18.5 \%$ and $12.4 \%$, respectively. And at the engine rated power condition, the BSFC reduction ratios of the three ORC systems are $6.1 \%, 7.4 \%$ and $5.2 \%$. The ORCR_1 has the best overall energy efficiency improvement on the ICE among the three ORC systems. By integrating ORC_Sim, ORCR_1 and ORC_pre with the ICE, the overall energy efficiency of the system can be improved by $6.5 \%, 8.0 \%$ and $5.4 \%$ under engine rated power condition, and when the ICE is under $10 \%$ load under engine rated speed, the maximum improvements of overall energy efficiency under the selected engine conditions are about $18.4 \%, 22.7 \%$ and $14.1 \%$.

\section{Acknowledgements}

451 The authors would like to thank the supports by EPSRC through (EP/K503885/1) for the project

452 Study of Engine Waste Heat Technologies, from NSFC-RS Joint Project under the grant number No.

4535151101443 and IE/151256.The first author also would like to thank for the encourage and 

for Outstanding Self-financed Students Abroad'.

456

457

458

459

460

461

462

463

464

465

466

467

468

469

470

471

472

473

474

475

476

477

478

479

480

481

482

483

484

485

486

487

488

489

490

491

492

493

494

495

496

\section{Reference}

[1] S. Quoilin, M.V.D. Broek, S. Declaye, P. Dewallef, V. Lemort, Techno-economic survey of Organic Rankine Cycle (ORC) systems, Renewable and Sustainable Energy Reviews, 22 (2013) 168-186.

[2] F. Vélez, J.J. Segovia, M.C. Martín, G. Antolín, F. Chejne, A. Quijano, A technical, economical and market review of organic Rankine cycles for the conversion of low-grade heat for power generation, Renewable and Sustainable Energy Reviews, 16 (2012) 4175-4189.

[3] T. Wang, Y. Zhang, Z. Peng, G. Shu, A review of researches on thermal exhaust heat recovery with Rankine cycle, Renewable and Sustainable Energy Reviews, 15 (2011) 2862-2871.

[4] C. Sprouse lii, C. Depcik, Review of organic Rankine cycles for internal combustion engine exhaust waste heat recovery, Applied Thermal Engineering, 51 (2013) 711-722.

[5] J.P. Liu, J.Q. Fu, C.Q. Ren, L.J. Wang, Z.X. Xu, B.L. Deng, Comparison and analysis of engine exhaust gas energy recovery potential through various bottom cycles, Applied Thermal Engineering, 50 (2013) 1219-1234.

[6] S. Song, H. Zhang, Z. Lou, F. Yang, K. Yang, H. Wang, C. Bei, Y. Chang, B. Yao, Performance analysis of exhaust waste heat recovery system for stationary CNG engine based on organic Rankine cycle, Applied Thermal Engineering, 76 (2015) 301-309.

[7] H. Tian, G. Shu, H. Wei, X. Liang, L. Liu, Fluids and parameters optimization for the organic Rankine cycles (ORCs) used in exhaust heat recovery of Internal Combustion Engine (ICE), Energy, 47 (2012) 125-136.

[8] M. Zhao, M. Wei, P. Song, Z. Liu, G. Tian, Performance evaluation of a diesel engine integrated with ORC system, Applied Thermal Engineering, 115 (2017) 221-228.

[9] G. Shu, X. Li, H. Tian, X. Liang, H. Wei, X. Wang, Alkanes as working fluids for high-temperature exhaust heat recovery of diesel engine using organic Rankine cycle, Applied Energy, 119 (2014) 204217.

[10] G. Yu, G. Shu, H. Tian, H. Wei, L. Liu, Simulation and thermodynamic analysis of a bottoming Organic Rankine Cycle (ORC) of diesel engine (DE), Energy, 51 (2013) 281-290.

[11] Y. Lu, Y. Wang, C. Dong, L. Wang, A.P. Roskilly, Design and assessment on a novel integrated system for power and refrigeration using waste heat from diesel engine, Applied Thermal Engineering, 91 (2015) 591-599.

[12] E.H. Wang, H.G. Zhang, Y. Zhao, B.Y. Fan, Y.T. Wu, Q.H. Mu, Performance analysis of a novel system combining a dual loop organic Rankine cycle (ORC) with a gasoline engine, Energy, 43 (2012) 385-395.

[13] E.H. Wang, H.G. Zhang, B.Y. Fan, M.G. Ouyang, F.Y. Yang, K. Yang, Z. Wang, J. Zhang, F.B. Yang, Parametric analysis of a dual-loop ORC system for waste heat recovery of a diesel engine, Applied Thermal Engineering, 67 (2014) 168-178.

[14] G. Shu, L. Liu, H. Tian, H. Wei, G. Yu, Parametric and working fluid analysis of a dual-loop organic Rankine cycle (DORC) used in engine waste heat recovery, Applied Energy, 113 (2014) 1188-1198.

[15] P. Song, M. Wei, L. Shi, S.N. Danish, C. Ma, A review of scroll expanders for organic Rankine cycle systems, Applied Thermal Engineering, (2014).

[16] S. Clemente, D. Micheli, M. Reini, R. Taccani, Energy efficiency analysis of Organic Rankine Cycles with scroll expanders for cogenerative applications, Applied Energy, 97 (2012) 792-801. 
[17] U. Muhammad, M. Imran, D.H. Lee, B.S. Park, Design and experimental investigation of a $1 \mathrm{~kW}$ organic Rankine cycle system using R245fa as working fluid for low-grade waste heat recovery from steam, Energy Conversion and Management, 103 (2015) 1089-1100.

500 [18] H.-C. Jung, L. Taylor, S. Krumdieck, An experimental and modelling study of a $1 \mathrm{~kW}$ organic Rankine cycle unit with mixture working fluid, Energy, 81 (2015) 601-614.

[19] E. Galloni, G. Fontana, S. Staccone, Design and experimental analysis of a mini ORC (organic Rankine cycle) power plant based on R245fa working fluid, Energy, 90, Part 1 (2015) 768-775. using scroll expander, Applied Energy, 87 (2010) 1260-1268.

[21] E. Winandy, C.S. O, J. Lebrun, Experimental analysis and simplified modelling of a hermetic scroll refrigeration compressor, Applied Thermal Engineering, 22 (2002) 107-120.

[22] L.C. Mendoza, J. Navarro-Esbrí, J.C. Bruno, V. Lemort, A. Coronas, Characterization and modeling of a scroll expander with air and ammonia as working fluid, Applied Thermal Engineering, 70 (2014) 630-640.

[23] F. Ayachi, E.B. Ksayer, P. Neveu, A. Zoughaib, Experimental investigation and modeling of a hermetic scroll expander, Applied Energy, 181 (2016) 256-267.

[24] A. Giuffrida, Modelling the performance of a scroll expander for small organic Rankine cycles when changing the working fluid, Applied Thermal Engineering, 70 (2014) 1040-1049.

[25] B. Twomey, P.A. Jacobs, H. Gurgenci, Dynamic performance estimation of small-scale solar cogeneration with an organic Rankine cycle using a scroll expander, Applied Thermal Engineering, 51 (2013) 1307-1316.

[26] Y. Lu, A.P. Roskilly, K. Tang, Y. Wang, L. Jiang, Y. Yuan, L. Wang, Investigation and performance study of a dual-source chemisorption power generation cycle using scroll expander, Applied Energy, epub ahead of print (2017).

[27] S.-C. Yang, T.-C. Hung, Y.-Q. Feng, C.-J. Wu, K.-W. Wong, K.-C. Huang, Experimental investigation on a $3 \mathrm{~kW}$ organic Rankine cycle for low-grade waste heat under different operation parameters, Applied Thermal Engineering, 113 (2017) 756-764.

[28] J. Ringler, Seifert, M., Guyotot, V., and Hübner, W., Rankine Cycle for Waste Heat Recovery of IC Engines, SAE Int. J. Engines, 2(1) (2009) 67-76.

[29] H.G. Zhang, E.H. Wang, B.Y. Fan, A performance analysis of a novel system of a dual loop bottoming organic Rankine cycle (ORC) with a light-duty diesel engine, Applied Energy, 102 (2013) 1504-1513.

[30] J. Song, C.-w. Gu, Parametric analysis of a dual loop Organic Rankine Cycle (ORC) system for engine waste heat recovery, Energy Conversion and Management, 105 (2015) 995-1005.

[31] Y. Lu, A.P. Roskilly, A. Smallbone, Recovering coolant and exhaust energy from a diesel engine using an Organic Rankine cycle (ORC), in: Poster session presented at The 3rd Sustainable Thermal Energy Management Conference (SusTEM 2015), Newcastle upon Tyne, UK., 2015.

[32] H. Yu, The Design, Testing and Analysis of a Biofuel Micro-trigeneration System, in: Sir Joseph Swan Centre for Energy Research, Vol. PhD, University of Newcastle upon Tyne, 2013.

[33] Y. Lu, A.P. Roskilly, A. Smallbone, X. Yu, Y. Wang, Design and parametric study of an Organic Rankine cycle using a scroll expander for engine waste heat recovery, Energy Procedia, 105C (2017) 1421-1426.

[34] A. Squared, Efficient $1 \mathrm{~kW}$ semi-hermetic scroll expander for lubricated or oil-free expansion with gases other than air, in, https://airsquared.com/products/scroll-expanders/e15h022a-sh/, Achieved on 8th Dec 2016.

[35] L. Liansheng, Scroll compressor, China Machine Press, 1998.

[36] V. Lemort, S. Quoilin, C. Cuevas, J. Lebrun, Testing and modeling a scroll expander integrated into an Organic Rankine Cycle, Applied Thermal Engineering, 29 (2009) 3094-3102. 
545 [37] G. Bamorovat Abadi, E. Yun, K.C. Kim, Experimental study of a 1 kw organic Rankine cycle with a 546 zeotropic mixture of R245fa/R134a, Energy, 93, Part 2 (2015) 2363-2373.

547 [38] F.-C. Software, Engineering Equation Solver (EES) software overview, in. 